\title{
ETHIOPIA AND ETHIOPIANISM IN SELECTED HISTORICAL PLAYS BY TSEGAYE GEBREMEDHIN
}

\author{
Haimanot Wassie (phD) ${ }^{1}{ }^{\mathbb{W}}$, Animut Getahun ${ }^{1}$ \\ ${ }^{1}$ Debre Markos University, Ethiopia
}

DOI: https://doi.org/10.29121/ijetmr.v7.i10.2020.784

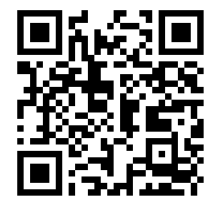

Article Citation: Haimanot Wassie (phD), and Animut Getahun. (2020). ETHIOPIA AND ETHIOPIANISM IN SELECTED HISTORICAL PLAYS BY TSEGAYE GEBREMEDHIN.

International Journal of Engineering Technologies and Management

Research, 7(10), 1-27.

https://doi.org/10.29121/ijetmr.v7

.i10.2020.784

Published Date: 16 October 2020

Keywords:

Ethiopia

Ethiopianism

Nationalism

Play

Tsegaye Gebremedhin

New Historicism

Unity

Patriotism

Hospitality

Freedom and Independence

History

Ethnicity

\section{ABSTRACT}

The main objective of this research was to show the representation of Ethiopia and Ethiopianism in Tsegaye Gebremedhin's selected historical plays (Tewodros, Petros Yachin Seat and Menelik). The basic research questions focused on how the depiction and representation can be explained and to answer these questions, new historical theoretical and critical approach was used. A purposive sampling method was used to select the sample plays that offer relevant data by using some criteria. The main method of data collection focuses on a close reading of literary and non-literary texts. After reading the plays critically, the major elements of Ethiopianism and historical events are identified, analyzed and interpreted. Accordingly, patriotism, unity, hospitality and freedom and independence were identified as elements of Ethiopianism, and the passion of Abune Petros, Tewodros at Meqdela and the battle of Adwa are identified as major historical events. The analysis mainly shows that these elements of Ethiopianism and historical events are depicted in the plays positively to promote the prevalence of Ethiopianism. The plays used direct, indirect and symbolic way of expression to articulate Ethiopianism. Generally, the plays are written based on the actual historical events which possess the mentioned elements of Ethiopianism and these elements are depicted in a way that advocates the need to develop the sense of Ethiopianism than ethnicity.

\section{INTRODUCTION}

\subsection{BACKGROUND OF THE STUDY}

The recognition that there is a relationship between literature and society is not new. Literature depictes the society and the society"s social, political and economic issues are pictured in literature. According to Arjun (2013:1), „the history of literature dates back to the dawn of human civilization and, literature and society are inseparable from each other, for literature cannot sustain without society and vice versa." Literature provides a framework for articulating our daily experience, and becomes an instrument for the discovery of new ideas. It thus either promotes our social consciousness by challenging our traditional standards or preserves norms and values that can shape mankind"s personal, social and human reality. MSC Okolo expresses this function of literature as it is „, vital tool for

(C) 2020 The Author(s). This is an open access article distributed under the terms of the Creative Commons Attribution License, which permits unrestricted use, distribution, and reproduction in any medium, provided the original author and source are credited. 
social building and reconstruction. And ... it provides basic intellectual frameworks within which people can interpret, perceive and transform human experience" (Okolo, 2005:19).

Ethiopian literature could not therefore deviate from this reality. Although, the emergence of modern literary creative writing either in Amharic or English language is a recent phenomenon, literature practiced for a long period in the country. The beginning of Amharic creative literature is tied with the publication of the first novel by Af ework Gebreiyesus in 1908 called Tobya (Libweled Tarik) following the introduction of western education, printing press, and consequently the publication of newspapers and megazins (Anteneh,2014;1).

Beginning from that time a bulk of literary products were published by various authors in different genres such as novel, short story, play and poetry with a purpose of more „art for society's sake than art for art"s sake" (Molvaer,1980;35). Various issues like the nature of mankind, human life, actions, progress, environment, and limitations are raised. The focus of this thesis, however, is on what is referred to as play. Play is "a composition intended to be performed that walks and talks before our eyes" (Okolo,2005:11). It may be different in type based on its content: historical, psychological, romantic, political, mythical and so on. Here, attention is focused on three historical plays by Tsegaye Gebremedhin namely Tewodros, Petros Yachin Seat and Menelik, which specifically on themes of unity, patriotism, freedom, and hospitality. These plays are national literature written by Tsegaye Gebremedhin. The writer of such plays, with the aid of imaginative creativity, renders an account of the nature of governance, authority, justice, equality, freedom and human rights among other themes.

Ethiopia is a multicultural, multilingual, multiracial and multi-religious country that required Ethiopians to understand each other in order to maintain the peace of the country. These diversified people are lived together. However, as many argued, since the practice of ethnic federalism in 1983 E.C, „Ethiopia has proliferated communal dissension and violence. ...rather than consolidating national unity, it has been further weakening social and historical bonds at the grassroots" (Tewodros, 2013; 290). Therefore, the sense Ethiopianism, which means "all ideologies and movements which aim to maintain the unity and integrity of the Ethiopian nation and state" (ibid), is attenuated and needs a reformation.

The researcher believes that literature can, "create awareness of possibilities for change" (Okolo,2005;10) by rising social consciousness. In this regard, historical literature takes a lion"s share. Play, which is the focus of this research, "often served as a tool of propaganda to influence people"s behavior and way of thinking because of its unique ability to reproduce images, movement and sound like a real life" (Deraman and Razak, 2018;82). Studying classic literature (plays) in which national identity is articulated in a best way could have a power to change the current condition of Ethiopia, which is characterized by ethnicity. Since,

„national or personal identity is a direct result of the presence of elements from the shared activities such as drama performances, cultural practices and other common factors in people's daily lives including language, history, culture and consciousness... and drama is an effective instrument for Identity formation" (Christine, (n.d);1).

For this reason, this study examines how Ethiopia and Ethiopianism is represented in Tsegaye Gebremedhin"s selected historical plays.

Poet, Louret and Playwrite Tsegaye Gebremedhin wrote 41 plays including the translations in his life (Ermias,2010;156). He is the main proponent of Ethiopia and Ethiopianism both in his life and works. Teferi Mekonen (in his introduction to Ermias Hussien "s book "Fire and Water")

said, „understanding Tsegaye"s life is, knowing as he is smiley of Ethiopia; his "poetics" and "Politics" is Ethiopianism. " (ibid). Most of his works deal the theme of Ethiopianism. According to Tewodros Gebre (in his introduction to the collection of Tsegaye Gebremedhin historical plays), the selected historical plays (Tewodros, Petros and Menelik) of this thesis are, „are embedded with motifs of Ethiopianism." (2001;vii)

Generally, the nature of s' ä gay ä G ä b ï r ä m ä d ï h ï n and his works are enriched with the theme of Ethiopia and Ethiopianism. The researcher believes that conducting a study on his selected historical play could serve as a solution for current political condition of Ethiopia characterized by ethnicity and prove the role of literature in shaping society. This on the other hand may add value for the movement to bring back Ethiopianism practiced by the government (governmental practice since February 24/2010 E.C).

\subsection{STATEMENT OF THE PROBLEM}

The current (2011 E.C) political mood of the country is the major motivation to conduct this thesis on the topic "Ethiopa and Ethiopianism in selected historical plays by Tsegaye Gebremedhin". The current political situation of 
Haimanot Wassie (phD), and Animut Getahun

Ethiopia during EPRDF period, has a sense that ethnic grouping took priority than Ethiopianism . There is "a shift from a sense of "Ethiopia or death" to "my ethnic group or death" which was not historical behavior of Ethiopia" (Teshome,2017;2). This mainly resulted from the practice of ethnic federalism political policy. In fact there were some symptoms of ethnic nationalism since 1960s, it was intensified more following "the change of the regime in 1991 which lead to recording of Ethiopian state and society along ethnic lines" (Merara,2003;7). This has significantly polarized the country"s politics, a polarization that could have a far-reaching implication. According to Merara, this was a deliberate action taken by the government to up hold power (ibid).

Art according to Leo Tolstoy, "...is a means of union among men, joining them together in the same feelings, and indispensable for the life and progress toward wellbeing of individuals and of humanity" (Tolstoy, 1899:4). It has a power to create common consensus.

The researcher"s interest to fill this problem gap,i.e, the prevalence of confusion and tension on Ethiopia and Ethiopianism created by ethnicity, through art of literature, takes the first initiative to conduct this research.

The second reason for conducting this research is the need to fill content gap of researches done on Tsegaye Gebrmedhin work. Though various researches have been conducted, as far as the researcher knowledge, they did touch his work specificaly on the represention of Ethiopia and Ethiopianism well.

The researchers high interest to support the recent movement of the government (after june 23,2010 E.C) to return the sense of Ethiopianism is another initiative for taking part the research.

\subsection{RESEARCH QUESTIONS}

The study was aimed to answer the following research questions:

1) How are Ethiopia and Ethiopianism represented in the selected plays?

2) How are the major historical events represented in selected historical plays?

3) What are the roles of the selected plays in promoting Ethiopia and Ethiopianism?

\subsection{OBJECTIVES OF THE STUDY}

\subsubsection{GENERAL OBJECTIVE}

The general objective of this study is to show the representation of Ethiopia and Ethiopianism in selected historical plays of Tsegaye Gebremedhin.

\subsubsection{SPECIFIC OBJECTIVE}

In addition to the above main objective, the research will have the following specific objectives;

- To explain how Ethiopia and Ethiopianism are represented in the selected historical plays.

- To examine, the representation of historical events in selected historical plays.

- To evaluate the roles of plays, in promoting and advocating Ethiopia and Ethiopianism.

\subsection{SIGNIFICANCE OF THE STUDY}

This study could have a number of advantages. Firstly, the study could be taken as a slack for the current aggravated situation of ethnicity in Ethiopia by providing an important understanding on the function of literature in shaping the society in general and the role of Tsegaye Gebremedhin selected historical plays in preaching Ethiopia and Ethiopianism in particular. This also supports the movement that nearly commenced to bring the sense of Ethiopia and Ethiopianism. Secondly, this study gives the opportunity for readers and researchers to see deep into other Ethiopian literature to understand how the concept of Ethiopia and Ethiopianism is reflected. And it could have some relevance to give information for writers who are able to get this research, on how historical events could be represented to articulate Ethiopia and Ethiopianism. 


\subsection{SCOPE OF THE STUDY}

The study focused on investigating representations of Ethiopia and Ethopianism in Selected historical plays by Tsegaye Gebremedhin. Louret Tsegaye Gebremedhin has written 41 plays including translations. However, the scope of this thesis is limited to three historical plays; Tewodros, Petros Yachin Seat and Menelik. This is because of their enrichment with the concept of Ethiopia and Ethiopianism which can help the researcher to cope up with the research objectives. Though Ethiopianism possesses many elements, this research paper make emphasis on patriotism, unity, hospitality, and freedom and independence. This is because the researcher believes that the sense of giving priority for ethnicity than Ethiopianism is emanated from the lack of the mentioned elements and preaching these elements through literature can bring change the situation. On the other hand, the term Ethiopianism has two dimensions: an Ethiopian Ethiopianism and black national movement. The black national movement is not the concern of this study. Although the selected works could be analyzed in different dimensions, in this paper the analysis is addressed from the point of view of the thematic representations of Ethiopia and Ethopianism. The writing style of the author and the writing techniques used in the plays were not the target of discussion, unless they have some relevance to the main purpose of the study.

\subsection{LIMITATIONS OF THE STUDY}

The researcher was interested in showing the representation of Ethiopia and Ethiopianism in Ethiopian literature during different period. However, temporal and financial matters affect his topic selection to be on one author and one genre. Therefore, this research is limited to only showing the representation of Ethiopia and Ethiopianism in selected historical plays by Tsegaye Gebremedhin, it did not exploit the representation of Ethiopia and Ethiopianism in Ethiopian literature as a whole. This makes the research not to be a general indicator of Ethiopian literature in representing Ethiopia and Ethopianism.

\subsection{RESEARCH METHODOLOGY}

\subsubsection{RESEARCH DESIGN}

Since the researcher constructs the representation of Ethiopia and Ethiopianism with a closer reading of selected works and other non-literary concepts like history, theology and psychology, constructivism paradigm was used as a basis for analyzing the literary works. The constructivism paradigm or epistemology asserts that meaning is constructed in mind through social interactions (Creswell, 2007:20-21). A researcher"s experience, knowledge, and social and cultural interactions are factors that lead to construct reality in a certain way.

The study also used a qualitative method as it enabled to carry out an investigation of qualitative phenomena, a representation of historical events in the plays. To investigate the representation of Ethiopia and Ethiopianism in Tsegaye Gebremedhin"s selected historical plays, the study used a theoretical approach of New Historicism. With a closer reading of the selected plays and related contemporary non-literary texts such as historical, political and legal documents based on the selected approach, different ideas and themes on representation of Ethiopia and Ethiopianism were constructed.

The study also employ hermeneutics research method since the concerns of the study were describing, interpreting and analyzing critically the representations of Ethiopia and Ethiopianism in historical plays. This method enabled the researcher to conduct an intensive investigation of patterns of representations of nationalism, and the relationships of history and plays. It also allowed the researcher to describe the historical events represented in the plays, and how they are represented.

\subsubsection{SELECTION OF SAMPLE PLAYS}

A purposive sampling technique was used to select the plays that represent Ethiopia and Ethiopianism. Accordingly, the following criteria were set. Firstly, historical events that were considered to be very significant in articulating Ethiopia and Ethiopianism were identified, based on readings of historical research works and books. Thus, Tewodros at Mekdela, Adwa and patriotic adventure of Abune P"etros were selected. Then the researcher 
Haimanot Wassie (phD), and Animut Getahun

identify the author, who prominently write on Ethiopia and Ethiopianism. Accordingly, TegayeGebremedhin, in expression of Teferi Mekonnen, who „is smiley of Ethiopia, and whose "poetics" and "Politics” is Ethiopianism" (Ermias,2010; xi) is selected. Then, plays in which the identified historical events represented were distinguished. Based on the above ropcedure, Six plays namely: Oda Oak Oracle, Callision of Altars, Petros Yachin Seat, Hahu Weym Pepu, Tewodros and Menelik, were selected from 41 plays written by the author for the study. Among these plays: Petros Yachin Seat (1955), Tewodros (1960), and Menelik (1982) was selected. This is because of their enrichment with "motifs of Ethiopianism" and the availability of plays in written form.

\subsubsection{SOURCE OF DATA}

The researcher has used both primary and secondary data from liberary and internet to his research work. The selected plays _ Tewodros, Petros Yachin Seat and Menelik, were used as primary data. This data sources were chosen among other plays based on the above criteria. The researcher has used document analysis to find data. The documents (secondary sources) were: books, MA thesis, journals, articles, and other related writings which give additional information about the selected plays, and theoretical approach.

\subsubsection{METHODS OF DATA COLLECTION}

The main method of data collection was a close reading of the selected plays and other related non-literary documents. The plays and other historical and political writings on the respective historical events were read closely and investigated in-depth. The research step in collecting data were reading all the selected works of the author, reread all pages and sentences that are related to research questions. Then extracts were grouped in to themes. After that, the researcher analyzes the identified data with different concepts.

\subsubsection{METHODS OF DATA ANALYSIS}

The data were thematically analyzed based on the theoretical approach of New Historicism. New Historicism is not used for examining literary texts in isolation; rather enable to relate the texts to the outer-context; or to the political, historical and cultural contexts of the respective historical periods. There were certain parameters used in analyzing and interpreting the plays with their historical contexts. The first step is examining the representation of Ethiopia and Ethiopianism either directly, indirectly or symbolically. How historical events are represented in the plays? Was the second step in analyzing the plays. This was examined with questions of; Do the writer reflect the whole history of a historical event neutrally, or take sides, by either supporting or opposing groups participating? Plausible or distorted, in relation to the actual historical event? Third, the representational role of the plays, in promoting Ethiopianism was examined. The data obtained in such inquiries were grouped, analyzed and interpreted in accordance with the concepts and frameworks discussed in chapter two. Extracts taken from the plays for illustration purpose were translated into English.

\subsection{ORGANIZATION OF THE STUDY}

The thesis consists of five chapters. Chapter one is the introduction. This chapter presents the background of the study, the statement of the problem, the research questions, general and specific objectives, significance of the study, scope of the study, limitations of the study, methodology and organizations of the research. Chapter two describes theoretical concepts related to Ethiopia, Ethiopianism, nationalism, new historicism and review of related research works. Chapter three, presents the analysis of representation Ethiopia and Ethiopianism in the selected historical plays of Tsegaye Gebremedhin. The last chapter presents of the conclusion of the research based on the findings of the study. 


\section{REVIEW OF RELATED LITERATURE}

This chapter has three major parts. The first part is concerned with the theoretical literature which comprises historical, sacial and political backgrounds of Ethiopia, nationalism and elements of Ethiopianism. The second part contains the review of previous works and the last discussed on the conceptual framework of the study.

\subsection{REVIEW OF THEORETICAL LITERATURE}

\subsubsection{ETHIOPIA: HISTORICAL, SOCIAL AND POLITICAL BACKGROUND}

When does Ethiopian nation and nation-state come to existence? What are facets of historic and modern Ethiopia? And What does the name Ethiopia signify? Are the main issues of discussion in this topic.

Ethiopia is a country with a long and pride-worthy history that „its beginning can be neither proved nor disproved" (Rogers, 1982:8). Conventionally, the historical foundation of Ethiopian state goes back at least three thousand years. This is based on the mythological origin of Ethiopia that can be traced back to the 10th century BC, which is tied with the relationship of king Solomon of Israel and Queen Sheba of Ethiopia. However, archeological evidences, like fossils of Lucy at Afar with 3.5 million years of age and heritages of the Stone Age at Melka Konture, prolong its history to be counted in a millions (Bahru, 1987:5). On the contrary, a minority voice shortens the country"s history to little based on the creation of the modern empire-state in the last quarter of the 19th century.

The etymological origin of "Ethiopia", based on the 15th C Ethiopian book called "Book of Axum", "is derived from the word Etïyop's, a name of twelfth king of Ethiopia"; king Etïyop's was the son of cush, whom his father was cam. (Ayele, 2004:5) Therefore, the name "Ethiopia" has an Ethiopian origin. However, some sources claim as "the name presumably was coined by outsiders, who lavish them with prise and "blamelessness" thereby, in the process, implanting external source to Ethiopian history and culture". (ibid) Others who are on the side of external ethymological source explain that the name Ethiopia is thought to derive from the Greek word which means "burnt face", and Ethiopia means "the country of burnt face" (Wallis,1928,VI;2).

A number of writers like; Homer, Herodotus, Starbo, Doudorus, pliny, and others, mention the name of the country Ethiopia frequently, but none of them supply information which enables us to describe its extent or to say exactly where its boundaries began and where it ended. Homer speaks (Odyssey, I; 23) of as there are eastern and western Ethiopians only where the "blameless" people inhabited, and that lay around the ocean which is presumably far to the south of the land of Greek (wallis, VII,1928;8).

Herodotus (B.C 484-425) says that the country Ethiopia lies "where the south declines towards the setting sun," and that is, "the last inhabited land in that direction." He also adds that, "the Ethiopians bordering up on Egypt, who were reduced by Cambyses when he made war on the long lived Ethiopians." The geographer Starbo placed Ethiopia to south of Egypt, and historian Pliny make it as, it far 246 miles to south of Syene (Wallis, VI, 1928; 35).

From the aforementioned statements, we may conclude that Homer and Herodotus suggust the name Ethiopia for the vast region of Africa which may include Sudan, Egypt, Arabia, Palestine, western Asia and India, Starbo and Pliny restrict the use of the term to peoples who lived in the northern and southern part of the valley of Nile. (Wallis, VI,1928;30, Rogers, 1928: 2)

And also we can decide that, the Hemer"s, Herodotus"s, Starbo"s and Pliny"s Ethiopia is not the contemporary Ethiopia rather the historic Ethiopia. This shows as our current Ethiopia has ancient facet „in which its territory covered a vast region of Africa, south Arabia as well as India, which comprises upper Egypt, Meroe, Nubia, Western Sudan, and the Arabian pensuela." (Rogers, 1982,8, Ayele, 2004:7)

While the contemporary Ethiopia which is established by Menilik II (Bahru,1991;36), is found in the horn of Africa bordered by Eritrea to the north, Djibouti and Somalia to the east, Sudan and South Sudan to the west and Kenya to the South. Ethiopia has a high central plateau that varies from 1,290 to $300 \mathrm{~m}$ (4,232 to 9,843 ft) above sea level with the highest mountain reaching 4,533 $\mathrm{m}(14,872 \mathrm{ft})$. It has a total area of 1,133,380 sq.km which comprises plateaus, mountain escarpments, rift valleys, below sea level depressions, lakes and rivers with resultant spectacular landscapes, waterfalls, and divergent climate and soils. (Helmut and Aynalem, 1998:1-4)

Ethiopia is a nation integrated not by one but by a combination of several kinds of objective relationships (economic, political, linguistic, cultural, religious, geographical, historical) and their subjective reflection in collective consciousness. This is the most decisive criterion and identification with thousands of years of recorded and 
Haimanot Wassie (phD), and Animut Getahun

uninterrupted statehood and its institutional and cultural legacy that we call historic Ethiopia. A foundation which is provided by the traditions and memories of ancient Ethiopia has evolved into the national culture of modern Ethiopia and it has been vital for its survival (Tewodros, 2013:53).

In the words of Tewodros, „Ethiopia is a "nationscape”. This is to mean a nation with a land and a land with a nation for a long period. As stated earlier the historical foundation of Ethiopian nation-state building goes back at least three thousand years" (Tewodros,2013:53). According to modernist theory, nation-state building emerged with ideology of nationalism. Therefore, nationalism is as old as the modern world, though it gained an unprecedented momentum during the 20th century. It is a driving force in fighting against colonialism and imperialism, and powered genuine struggles for freedom and social justice everywhere. Nationalism is today a maker or breaker of states, an agent of peace, stability and progress as well as a cause of horrendous bloodshed, destabilization and destruction (ibid). The next discussion is focused on the issue of natinionalism and Ethiopianism.

\subsubsection{NATIONALISM AND ETHIOPIANISM}

\subsubsection{NATIONALISM}

Various scholar difine nationalism based on their understandings. Bart Bonikowski (2008), defines nationalism by classifying into three broad approaches: political, psychological, and cultural based on various scholars definitions. The first deals primarily with nationalism at the level of the collectivity and its elites, the second at the level of the individual, and the third at the level of individuals embedded in structures of social relations that pattern the cultural resources to which the individuals have access.

\section{Political Definition}

Nationalism according to Gellner (1983:1), is "primarily a political principle, which holds that the political and the national unit should be congruent." This political principle, For Breuilly (1985:3), involves three fundamental assumptions: "there exists a nation with an explicit and peculiar character; the interests and values of this nation take priority over all other interests and values; the nation must be as independent as possible" (Bart, 2008:7). Bart explains these functions of nationalism as:

"an ideology that can be consciously utilized by political movements to further their goals, but which also exists at a less explicit level as a frame through which individuals understand their social world. The political perspective has been used to study the historical origins of modern nation-states, as well as efforts by contemporary non-state actors to establish sovereign authority over a territorially bound population" (Bart, 2008:8).

Psychological Definition: As Bart stated in his research, this conception of nationalism emphasizes the relationship between the individual and a generalized image of the nation. Based on this, nationalism defined as the "devotion to an ideal, abstract, unrealized notion of one"s country, often coupled with a belief in some wider national mission to humanity" (Lieven 2004 as cited by Bart, 2008:9).

Cultural Definition: According to Bart, it is "a set of shared scripts and symbols used by individuals to make sense of their world and to justify their strategies of action" (Bart, 2008:10). According to Billig"s (1995), nationalism consists of "ideological habits which enable the established nations of the West to be reproduced. [...] Daily, the nation is indicated, or "flagged", in the lives of its citizenry." Nationalist "idioms, practices, and possibilities" and "ideological habits" can be identified at different levels of analysis, includingthe nation itself, organizations and socio demographic groups, and individuals (Bonikowski,2008;10).

Based on the above discussion, we Bart define nationalism as:

"the self-understanding of individuals and groups framed in terms of their membership in a broader collectivity coterminous with the territorial, social, and legal boundaries of an actual or potential nation-state. This selfunderstanding is produced through the interaction of individual cognitive schemata, shared cultural understandings contained in various forms of public discourse, and institutional rules and conventions" (Bart, 2008:1

Even though there are more than six types of nationalism, most intelligentsias agree, that there are two types of nationalism. These are ethnic and civic nationalisms. (Vijay, 2015; 9)

Ethnic Nationalism: Though nationalism does not support the belief of superiority based on ethnicity, some nationalists support ethnocentric nationalism. For some nationalists, national community is based on language, 
ethnicity, religion, culture. They try to find out national purity from all these. For them minorities are not truly parts of national community. If there is a myth engaged with the homeland, then it becomes superior to them to connect and form a community sharing the same pride of mythic homeland (Vijay, 2015;8).

Civic Nationalism: it defines the nation as an association of people who identify themselves as belonging to the nation, who have equal and shared political rights, and allegiance to similar political procedures. For civic nationalism, a nation is not based on its ethnic history but on political entity. Civic nationalism is well defined by Ernest Renan in his lecture "What is a Nation?" (1882), where he defined the nation as a "daily referendum" dependent on the will of its people to living together. Civic nationalism is compatible with liberal values of freedom, equality, tolerance, and individual rights. (ibid)

\subsubsection{ETHIOPIANISM AND ITS ELEMENTS}

Ethiopianism in this study is intended to stand for "all ideologies and movements which aim to maintain the unity and integrity of the Ethiopian nation and state, and is synonymous with civic nationalism. Ethiopianism in this sense, which loosely translates as "Etyop"iawinet" or "Etyop"iawi Bihertegnet" (Tewodros, 2013:34). These ideologies are a set of the Ethiopian patriotic values aimed at creating Ethiopian identity. These values may be a belief in devotion, loyalty or allegiance to Ethiopia or its flag, traditions, customs, culture, symbols, institutions or forms of government.

The original ideology of nation-state was civic nationalism due to its emphasis on the common citizenship rather than a unique culture or language as a measure and substance of nationality (Tewodros, 2013:6-7. However, the emergence of ethnic nationalism makes civic nationalism of the old continuous nations on defensive position. The trend of nationalism in Ethiopia is parallel to this situation. During the first nation-state building, Ethiopia practiced civic/Ethiopianism/Ethiopian nationalism. The name used to call all the nation was Bhere Ethiopia. The sentiment of Ethioianism takes priority than ethnic nationalism. Citizenship was given more priority than ethnicity. This was practiced until the fall of Dergue regime. However, after the fall of Dergue regime (1983 E.C), there is a shift from Ethiopia or death to my ethnic group or death and Ethiopianism take a defensive position (Tewodros, 2013). The longstanding values and traditions, which were serving the nation as part of the greater member has been deconstructed and decentered from the mainstream of politics. Indeed the present ruling government after june 24, (2010 E.C) is trying to bring back the sentiment of Ethiopianism.

Teshome Abera who had made a study on this issue entitled Ethiopianism principles (2017) stated that Ethiopianism is historical and transferred from our forefathers and the quality of possessing Ethiopianism is the basis for imprinting image-changing history including the victory of Adwa. He also mentioned as patriotism, unity, concern for others, respecting others, accommodations of difference and independence are principles or elements of Ethiopianism in relation to individuals contribution and Ethiopians in general (Teshome,2017;3). The researcher prefers to use some of these elements, which are most important to solve problems of ethnicity in the present Ethiopia as a base of the analysis with a little nomenclature improvement.

\section{Patriotism}

Patriotism was one of the best feature pillars in Ethiopianism. It is "related to love and loyalty towards the country. One is considered as a patriotic citizen when their belief, practice and action meet the characteristic of being patriotic." Patriotism further means showing more regard and loyalty to his/her nation rather than self-ethnic groups, states, local government areas and towns.

D.A. Falade and M. Falade (2013), described patriotism as the extent to which citizens trust and support their government and the extent to which the government trusts and supports its citizens. Aspects of patriotism include: absence of bribery and corruption, love of one"s country, obeying laws, paying taxes, loyalty and voting at elections (pp.59). The writers also expressed it comprehensively which constitute, the spirit of patriotism is not limited to one"s willingness citizens serve in the field of national defense such as military and police only, but they include all aspects of society"s economic, educational, cultural, sports and variety (as cited in Deraman and Razak,2018:88).

Primoratz classified patriotism into two types, which are value-based patriotism and egocentric patriotism. Value-based patriotism is referring to "the loyalty and love of a nation to the country is due to certain factors that can profit such as the achievement of the country in terms of economy as well as other privileges available in that country. These groups often raised the issues such as what is the contribution of the country to me while the question 
Haimanot Wassie (phD), and Animut Getahun

of what my contribution to the country will be ignored. To put it in a simple way, if the country does not provide benefits to them, the loyalty to his country will disappear this. This type of patriotism can be regarded as materialistic, shallow and inaccurate" (as cited by Deraman and Razak,2018:86).

Meanwhile egocentric patriotism refers to „one"s love and loyalty to his country simply because "it is his country" but not because of the country"s ability to provide certain achievements and privileges for himself. Thus, egocentric patriotism presented by Primoratz is seen to be better than value-based patriotism because the nations love for the homeland is unconditional. In general, egocentric patriotism can be judged as a sincere love for the country because the nations do not expect anything from it when compared to values-based patriotism" (Deraman and Razak,2018:87).

In Ethiopian context, the Adwa victory and the wars before Adwa and after it are witnessing how Ethiopians are proud of their country. They died to make their native land free from colonial power. They sacrificed themselves for the best possible future of the country. Emperor Tewodros II when defeated by British expeditionary forces, decided to commit suicide instead of living under them as a slave and seeing his country fallen under the colonial administration. Emperor Yohannes IV is beheaded while fighting Mahdist forces. The Ethiopians at Adwa defeat Italian forces by Ethiopian army lead by Emperor Menelik. These leaders are kings. However, they suffered and sacrifice their life for the freedom of their country. It is this principle that was taken by other black countries as an epitome and initiates them to liberate their country from the colonial yoke. The lesson we learned from these kings is that they are on the battle field with their army and ordinary citizens fighting the enemy. They were not in their palace and waiting for the report about the progress of the war. It is because of this that they earned an immortal name by their sacrifice for their country (Teshome, 2017:3-5).

\section{Unity}

Unity is one quality that Ethiopians experience for a long period. National unity and integration amongst the citizens is directly related to inter-ethnic relations in a country where multiracial, multilingual and multicultural society is inhabited. They have been standing together, who and whatever comes on their country. They leave their difference aside and stand together for their common destiny. If we take the major event, victory of Adwa, it was the result of all nations, nationality and peoples around the country. The word of Henock express this as, "Though the battle of Adwa was led by Menelik, who marshaled the support of local lords, the credit also goes to the wide array of ethnic groups and peoples with diverse linguistic backgrounds" (cited in Teshome,2017;5).

Besides the ethnic unity, during the battle of Adwa, Menelik calls for all Ethiopians to march for Adwa to defend their country from Italian fascist army. The response given to Menelik by all group of people from all corner was speedy. Keeping aside their differences, they marched to Adwa and defeated the Italian army equipped with latest armament and machinery by the traditional instrument. Then, it is the unity of the Ethiopians at the time that defends their country and brought the well-equipped Italian forces down. It is a victory that redefines Ethiopians relation with the super powers of the time (Bahru, 1987;63).

\section{Hospitality (Homage)}

Hospitality involves welcoming strangers - not just the rich and respectable strangers, but also the oppressed, persecuted and absolute strangers who may not posses much to share or with whom one may not always have much in common (Puspa, 2012:1). Strangers according to Simmel, „may be those "who comes today and goes tomorrow” or "who comes today and stays tomorrow" and may be from abroad or within a group whose boundaries are analogous to spatial boundaries" (cited by Puspa, 2012:2).

In Ethiopia, strangers may possess the above descriptions, and Ethiopians accept them with their respective conditions. Throughout history, Ethiopians have a palpable name of hospitality. One history is recorded during the time where followers of Mohammed prosecuted in their place. Mohamed ordered them to go to the land governed by the Christian king of the time to seek refuge which Mohamed called the land of peace and justice. He ordered his followers without fear that they forced to change their religion and accepted Christianity. His followers and relatives were received by the Christian king with dignity and respect (Teshome, 2017; 6).

\section{Freedom and Independence}

"Hitherto God has graciously preserved our native land. He has permitted us to conquer our enemies, and to reconstitute our country. It is by the grace of God that I have reigned hitherto, and if my death is near I have no 
anxiety on that account, for death is the fate of men. But up to this day God has never humiliated me. In the same manner He will sustain me in the future.

"An enemy has come across the sea. He has broken through our frontiers in order to destroy our country and our faith. I allowed him to seize my possessions and I entered into lengthy negotiations with him in hope of obtaining justice without bloodshed. But the enemy refuses to listen. He continues to advance; and like a mole, undermines our territory and people.

"Enough! With the help of God, I will defend the inheritance of my forefathers, and will derive the invader back through forces of arms! Let every man who is strong join me! And who is not strong, let him pray for me!" (Punkhrust,2005:90)

The above quote was a proclamation taken from Richard Punkhurst"s Historic Images of Ethiopia $(2005 ; 90)$ which was declared by Menelik II, on September 1896 G.C, to mobilize his people against Italian invasion. Based on the king"s declaration, for they were patriots of their country and honor of their king, strong men defeated the Italian at the battle were joined him and fought with the largest and best-equipped Italian force, which lastly resulted Adwa in 1896. This victory caused the European power to flock to the new capital, Addis Ababa, to sign treaties, open up legations and acquire concessions. Menelik played important role in modernizing the country by opening modern schools, by constructing different bridges, forming state bureaucracy and diplomatic relation with other countries (Teshome, 2017; 4).

Ethiopia, the only state to survive the European scramble for Africa, had become a beacon of freedom for the black world. Daniel Thwaite, a historian of South Africa, explained, "Ethiopia"s prestige in repelling invasion, and in having remained unconquered throughout the centuries, is practically unfathomable. To Africans in general, not only to those who invoked her as a liberator, she stands as a granite monument, a living exponent of the black race, the shrine enclosing the last sacred spark of African political freedom, the impregnable rock of black resistance against white invasion, a living symbol, and incarnation of African independence."(cited in Pankhurst,2005;91)

As Bahru (2008) said, the victory of Adwa "define Ethiopia and Ethiopians more than any other events in modern history," and had also a great impact on firing the black movement called Ethiopianism which was started in 1880 in south Africa (cited by Teshome, 2017:2). The Adwa victory and the war before Adwa and after are witnessing how Ethiopians are proud of their country. They died to make their native land free from colonial power. They sacrificed themselves for the good will of their country. In general, Ethiopia is a country inhibited by Ethiopians with a prolonged history. And characterized by patriotism, unity, hospitality/homage/, and freedom and independence.

\subsubsection{NEW HISTORICISM}

New Historicism is a literary critical approach and theory that emerged in America in the early 1982. It was basically a reaction against the earlier Schools of Criticism - particularly against New Criticism, Formalism, Structuralism, and Deconstruction which were all concentrating exclusively on the analysis of the language of the texts in which distinctions between literature and its contexts and between literary and non-literary texts were practiced (Hisham, 2016: 17). New criticism, formalism and structuralism are characterized by their neglect of contexts - historical and cultural contexts in which works of literature are produced. While, „the initial endeavor of new historicism is to relocate the literary text among nonliterary "discursive practices" of an age by making use of documents like chronicles, legal reports, pamphlets and by analyzing other forms of art like painting, sculpture, music, etc" (Doğan,2005;82).

Some of the main proponents of New Historicism are Stephen Greenblatt, Louis Montrose, Catherine Gallagher, D. A. Miller, Joel Fineman and Walter Benn Michaels.

New Historicism is characterized by some major principles. The method was intended to be a shift in emphasis that would ground the study of literature in its historical context, or more precisely within the different discourses of the time - to stress the importance of historical materials in the fabric of literary texts. As Bartens express:

New historicists assert that in understanding a literary work, historical, political, biographical, and other forms of writing play important roles. Conversely, literary texts equally give useful knowledge and insight in understanding historical or political texts. It is characterized by inter-textuality. The literary text is read and understood in relation to other literary and nonliterary texts and other documents of the same era. (Bertens, 2001: 180, cited in Anteneh, 2014; 39). 
Haimanot Wassie (phD), and Animut Getahun

The concept of New Historicists viewing a literary text as a historical process was expressed by Montrose"s „the historicity of the text and the textuality of history. "Anteneh describe this as:

„New historicists understand history as embedded in texts, and, at the same time, texts,in one way or another, represent history. A new historicist "accepts Derrida"s view that there is nothing outside the text, the special sense that everything about the past is only available to us in textualized form: through the ideology, or outlook, or discursive practices of its own time, through those of ours, and through the distorting web of language itself". Our knowledge of the past is constructed from these practices" (Anteneh, 2014: 37).

According to Bertens(2001), the relationship between literature and context is multi directional. Literature can be simultaneously considered as a product of history, and in turn as a tool that has significance in the making of history. Literature represents history, but it is not a mere representation of history. It is rather actively involved in the shaping of history, and gives insights into the formation and interpretation of historical and political moments. Literature reveals the processes and tensions by which historical changes were brought about, and may motivate changes in history. It may, at the same time, reveal the social and political ideas of a particular time in history and also instigate the need for rupture or the need for change in that political system (cited in Anteneh, 2014: 37).

According to new historicist, no text and author could be considered autonomous and absolute. The author was reduced to author-function that the institutional and cultural forces determined the function of him and literature produced. Dogan (2005) describe this as:

"Literature, for new historicism, is a social and cultural creation constructed by more than one consciousness, it is not autonomous, and it cannot be diminished to a product of a single mind. Therefore, the best way of analysis is achieved through the lens of the culture that produced it. Literature is a specific vision of history and not a distinct category of human activity. Man himself is a social construct; there is no such thing as a universal human nature that surpasses history: history is a series of "ruptures" between ages and man. As a consequence, the critic is trapped in his own historicity. No one can rise above their own cultural formations, their own ideological upbringing in order to understand the past in its own terms. Therefore, it is impossible for a modern reader to appreciate a literary work as its contemporaries experienced it. As a result, the best approach to literary criticisms to try to reconstruct the "ideology" of its culture by taking the text as its basis and by exploring diverse areas of cultural factors" (Doğan,2005;82).

Power relations of a particular era shape how literature is produced, distributed and consumed. Literary texts that were prohibited once might at times be free and encouraged to be published, distributed, and read following changes in the cultural and political system. For new historicists who are influenced by Foucault, power relationship is not unidirectional in which the powerful dominates the powerless; or the upper class dominates the lower class. It is rather bi-directional where the lower class, in some way, resists the upper class, the factory workers resist the injustices of the factory owners and their respective directors. New historicists believe that literary texts have functions within a network of power relations in society. Since literature is a discourse characterized by power relations, it can be considered as "a loyal watchdog, patrolling the fences of a conservative social order"; it can also equally serve as an agent that brings resistance and change in the power relationships (Brannigan, 2001: 172 as cited by Anteneh, 2014;41).

For new historicists, literature like any discourse reflects ideology time. It reflects and shapes individuals, groups, and even a nation. Literary text is a -and place-bound verbal construction that is always, in one way or another political; because it is inevitably involved with a discourse or an ideology, it cannot help being a vehicle for power" (Bertens, 2001: 177, cited by Anteneh, 2014;46).

In spite of the contribution of New Historicism to literary theory and criticism, there have been some criticisms against it. Formalists, structuralists and deconstructionists criticize New Historicism for its focus on historical contexts and political orientations. It is criticized for its rejection of both the autonomy and individual genius of the author and the autonomy of the literary work. New Historicism is also criticized for its failures to meet form of the literary work (Brannigan, 2001 as cited Anteneh, 2014;43).

The application of New Historicism as one of the tools for analyzing the plays in this study helps to achieve the main objective of the study by creating a relationship between the plays and the social and historical contexts of their writing. Furthermore, the tool facilitates intertextual reading in which the study of the plays could be related to historical, political and legal documents. It further helps to investigate the relationship between the history and the literature and the role of literature in shaping the society. 


\subsection{REVIEW OF PREVIOUS WORKS}

The researcher has been able to read local critical reviews and research works that in one way or another are related to the current study. In this regard, he came across one article and one thesis, which are concerned with Ethiopianism and Tsegaye Gebremedhin, respectively.

The first is a critical Article by Teshome Abera presented at Addis Ababa Science and Technology University in 2017 E.C. The aim of the article is to show the past history of Ethiopia and inform the new generation to inherit how the heros and heroines of the past generation defended against the injustice inflicted upon the country by invaders and how Ethiopianism become a movement of all black race in the world. Teshome conducted his study by understanding the importance of examining the past inorder to recognize the present. Based on this, he identifies principles of Ethiopianism, which are patriotism, unity, concern for others, hospitality, accommodiations of difference and freedom and independence. He discussed on the relevance of these elements in relation with the black movement "Ethiopianism" in general and Ethiopia in particular to restore peace, national pride, and development.

Teshome"s critical article has a relationship with the concern of this study. Firstly, the base of the discussion for both the article and my research are elements of Ethiopianism. Elements of Ethiopianism in my research are taken from Teshome"s Article. Secondly, the goal of the two studies is to awake the present generation. The difference between this research and Teshome"s article lies in the object of study:its focus on historical plays (literary text), while Teshome"s study dealt with data from proper history.

The second research is Solomon Tesema"s MA thesis entitled Interdisciplinarity in Tsegaye G/medhin"sHahuweymPepu (2007, an MA thesis at Addis Ababa University. Solomon conducted his research with the main aim of investigating interdisciplinarity of the play Hahu Weym Pepu. To achieve his goal, he used hermeneutic approach as a method of analysis and interpretation. Proving the interdisciplinary nature of Hahu Weym Pepu is his final finding. This thesis helped the current researcher by providing valuable information about the biography of the author.

While, my research is aimed at, showing the representation of Ethiopia and Ethiopianism in selected plays of Tsegaye Gebre Medhin. To do this, the researcher identify elements of Ethiopianism from the plays and analyzed them by theoretical approach of New Historicism. The object of our study, i.e, the three plays of Tsegaye Gebremedhin, is the issue that makes the two study related.

\subsection{CONCEPTUAL FRAMEWORK OF THE STUDY}

\section{Literature, Nationalism and New historicism}

Literature refers to the imaginative, creative and aesthetic writing organized in the form of drama, verse or prose. The play, which is the concern of this study, is one of the genres of creative literature in prose or verse form. Literature extends its territory from the earth to the sky. It has a close connection with different issue and discipline. Evaluating the depiction of Ethiopa and Ethiopianism in selected historical plays to promote Ethiopian nationalism through theoretical approach of new historicism is the main issues of this research. Here the interconnection between literature, nationalism and new historicism make the edifice of this research. Therefore, the researcher develops the conceptual framework of the research as follow.

According to a New historicism literary theory, identity is fashioned by social institutions. Literature is one of social institution produced by a society and used as a tool of (re)shaping the culture of the society. Literature can be said to be a product of history; it is in the history of civilization of a society that literature emerges and grows. And literature always constitutes history, because literature deals with human life and nature, and consequently, it cannot be free from history. Thus, literature is constructed from history and gives access to understand the past and to create present and the future. This is what new historicist call textuality of history and historicity of the text.

As an institution, literature meets the authors with the readers. On the one hand, writers could reflect and represent historical contexts positively or negatively. They also influence contexts in different degrees. On the other hand, the reader of the text is influenced and shaped by the writer"s reflection and representation of contexts. Thus, the readers in order to understand the text fully, should have contextual knowledge of the text. If they are with munitions of contextual knowledge, they can construct ideas and themes from their reading and learn something from texts. They might be influenced by what they read and in turn take part in the struggle held to change the existing contexts. Ethiopianism in Ethiopia was practiced for a long period of time with a better past than the present. 
Haimanot Wassie (phD), and Animut Getahun

The practical situation of the past is depicted in Ethiopian classic literature. Analyzing and interpreting those literature (historical) helps to understand the past and to formulate today as well as the future.

\section{ANALYSIS OF ETHIOPIA AND ETHIOPIANISM IN SELECTED HISTORICAL PLAYS BY TSEGAYE GEBREMEDHIN}

This section deals with the analysis of Ethiopia and Ethiopianism as represented in selected historical plays. The representation of Ethiopia and Ethiopianism in general; and patriotism, unity, hospitality and freedom and independence in particular are is discussed. The way of representing major historical event as well as its role in promoting ethiopianism are examined and analyzed.

\subsection{SYNOPSIS OF THE PLAYS}

\subsubsection{SYNOPSIS OF PETROS YACHIN SEAT (THE PASSION OF PETER)}

Petros Yachin Seat is a historical play reflecting on the history of martyor Abune Petros who carry out a patriotic adventure during the Italian occupation. It was published in 1955 E.C. The story has three characters, nmely; Hailu, Girsha and Rodelfo participated in the play. Hailu is a religious leader who believes as Ethiopia is not under the control of Italy and struggles in order to make this true.

He also teachs that allying with Italy and living comfortable life is "a death of death" and living such a life is worse than death for his country. Girsha, on the other hand, is an Ethiopian who allies with Italy and, Rodelfo is an Italian General in Ethiopia. The whole play is full of struggles and arguments of Hailu on the one side and, Girsha and Rodelfo on the other side. The argument, that deals between leaving for faith and living for wealth.

Rodelfo and Girsha forced Hailu to change his stand on Italy. But Hailu strengthens himself when temptation increased from time to time. Lastly, Italians and Girsha together execute him. His death was an event that paves the way for the creation of new Ethiopia.

\subsubsection{SYNOPSIS OF TEWODROS}

This play is based on a true story of king Tewodros who administered Ethiopia from the 1947-1961 (E.C). The play was published in 1960. The story from the beginning to the end deals with both in Tewodros administration and in the events of the day. The first part shows the letter which says, „I found Ethiopia to break into the mouths of mafia. So, I outlawed and determined to rebel". At this time the play shows the occurance of burial at the palace. This letter angered Empress Menen greatly. In answer to his letter, she sent a message to the messenger who insulted his mother and his mother. Tewodros casts his emotions in touch with his fiancé. On both sides, preparation will be made for the battlefield. The warriors of Menen, Wondyirad, lie in the field with 4,000 warriors. Tewodros with Gelemo and Gebrye, were going to the battlefield with some 700 woriors. They capture their enemies. Empress Menen become angry and decide to fight with Tewodros, yet she is subject to defeat and spoil. Her son runs away to Gorgora. The winner will be brought in the Royal Palace.

The son of captive Menen, Ali, sends a letter to Tewodros, which begg to send his mother home and to let him know that he has received as a leader. Teodros sends her back to her son by arguing, as there is no way to communicate with power and race. After this, he launch the campaign to Wollo, Shewa, Gojam and other parts of the country to create unified and strong country. Victory was in hand and he strives to preserve the modern administration system. He reduces the number of priests, and puts the soldiers in charge of wages. A modern punch called Sapotolpol was made. His wife is furious.

The princes rebel against Kassa. He takes a brutal action. This action separated him from the public and leaves only with his loyal companions. On the other hand, the delay of response to get military aid from the UK, forced Tewodros to arrest British nationals who came to Ethiopia to promote religion. Britain sent its warriors to Ethiopia to free its citizens. The battle is over, and he destroys himself. 


\subsubsection{SYNOPSIS OF MENELIK}

Menilek is a long play written in 1982 E.C by making king Menilek of Ethiopia as the base and main character of the story. It consisted of three acts. The play narrates beginning from the scram of Menilek at Mekdela to his death. Menilek in the play is a wise and observant man who gives priority for peace than war. When events that lead to conflict was happened, he give a chance to solve them by discussion. War is his last alternative. Through this process, many historical events are narrated artistically.

The battle of Adwa is the major historical event narrated in the play broadly. The war takes place between Ethiopia and Italy. Article 17 of Wuchale Treaty is the incident that raises the conflict. The meaning of Article 17 of the treaty in Amharic is different from the Italic virsion. The Amharic meaning assured the freedom and independence of Ethiopia, while the Italian breave of Ethiopian independence. For this reason king Menilek ordered to amend the treaty. But the Italian refused to do so, because they wants to invade Ethiopia. Ethiopia"s refusal to accept the treaty enforced Italy to invade her in the North direction. Menilek toterate and inform Italy to refrain from war action, though they gave him their deaf ear to his call. After that Menilek declare a war proclamation to his people. All Ethiopians, irrespective of their race, gender, age and religion, were campaigned to the war field. Lastly, Ethiopians and Italians fight at Adwa and Ethiopia becomes the winner. Beginning from that Ethiopia becomes the symbol of freedom and independence in the world.

\subsection{ETHIOPIA AND ETHIOPIANISM IN THE SELECTED HISTORICAL PLAYS}

The selected plays try to represent Ethiopia and Ethiopianism in various ways. The representation begins from defining the etymology of the name Ethiopia. An operational definition of Ethiopia and Ethiopianism is also portrayed in the selected historical plays. Among the selected plays, it is in Mï nili $k$ that Tsegaye define and describe Ethiopia and Ethiopianism in a better way. As it was expressed here under in the play Ethiopia is "(

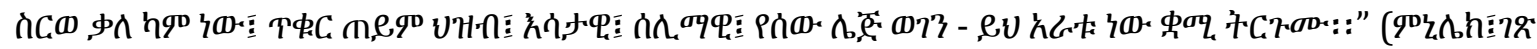

206) ["the word Ethiopia is derived from Cushitic language stem and it is to mean black tan skinned people, peaceful, heroic, and being a human being" (Menelik, pp.206)].

Similarly, the meaning of Ethiopia is also delivered in the play as:

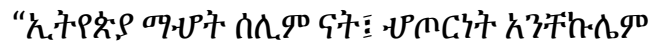

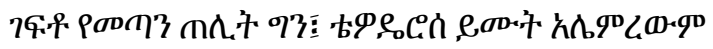

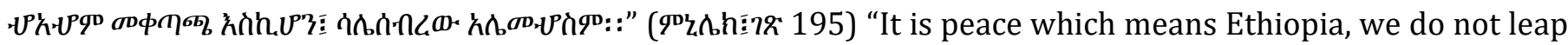
for war

But for encroacher, in the name of Tewodros I am unmerciful

As if it were a tutiton to the world, I would not go back." (Menelik, pp.195)

Here above, Ethiopia is explained as it is a peaceful country that do not leap for war but insufferable on its sovereignity. Its peaceness is for those who do not come on her sovereignty. If they touch her benefit and invade her, it is like a fire that destroys a joungle. This is what history tells us.

Further Ethiopia is represented as a country with a long and pride history where civilization was prevailed once and disappeared through process. In the play of Menilek this is stated in the following manner;

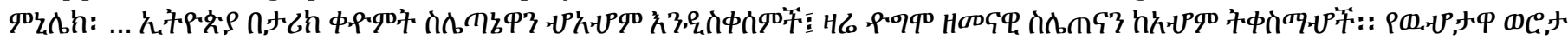

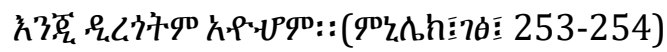

"...Ethiopia is a country with a long history of civilization in the history of the world. Today, she continues to receive modern civilization from around the world. The reward is a blessing but not a debt." (Menelik, Pp.253-254)

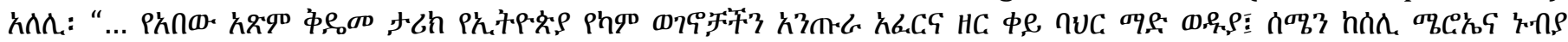

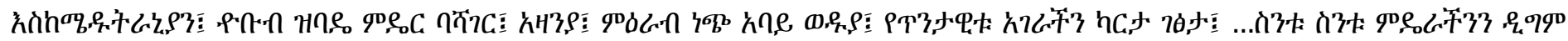

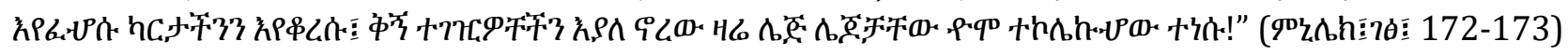


Haimanot Wassie (phD), and Animut Getahun

Alula; "Mountains and beyond Red Sea, North of Kesela, Meroe and Nubia to the Mediterranean, Beyond the Zagreb, Antaranar, West White nile, for Abyssinians of Ethiopia, Map of Our Ancient Patterns, ... How many of us have been looking at reclaiming our planet as our colonies Stay alive today!" (Menelik, Pp.172-173)

The above extract shows that Ethiopia is an ancient country that its geographical location covered a large portion of Africa and Asia, which is broader than its current territory. Further, it shows, as Ethiopia is a source of civilization to the world.

As history tells, „Ethiopia is an ancient country in which Homer and Herodotus give the name Ethiopia for the vast region of Africa which may include Sudan, Egypt, Arabia, Palestine, western Asia and India" (Waliss,VI,1928; 2). This shows that the writer of the play used the actual history to tell the audience about what Ethiopia has been in the past and at present.

The representation of Ethiopia and Ethiopianism in the plays is not limited to mention its pride historical position. It also explains as this history is not resulted in a simple way, rather in adventure between external and internal enemies and it shows the means how that was achieved.

In Petros Yachin Seat, we observe this situation through everything that Hailu did and has been done on him. Hailu is a faithful man who cares for his country freedom and independence. He is a strong man who believes that this freedom is brought through everyone"s sacrifice for his or her country and takes commitment to be that. But his belief is highly tempted by internal and external forces. Girsha is the internal threat from Ethiopia; and Rodelfo is the external one from Italy. The extent how much enemies from inside and outside was fore, is expressed in Hailu"s word as;

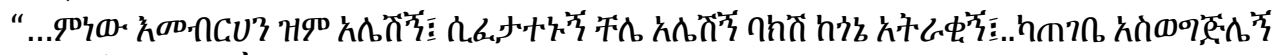

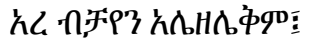

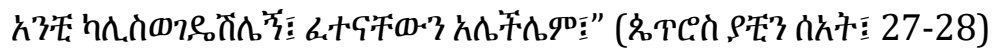

“...Why you just ignore me Merry, and neglect me when they"re tempted Do not hold me back from you.

I cannot succed alone;

If you did not make them evict, I cannot withstand their test." (Petros Yachin Seat,27-28)

Even though he said this, as narrated in the story, he does not regret back from his first stand of sacrifice. He continued to be martyrdom and did it.

In Tewodros, this theme is expressed in the story of Kassa. Kassa was a patriotic leader who efforts to unite Ethiopia and take different measures to achieve his goal. He try to form one andmodern administrative center in Ethiopia. This does not give comfort for those who were getting benefit from the disunited Ethiopia. This brings internal disagreement between the progressive Kassa and the conservative group. Finally, Kassa left with some loyal warlords and suicide himself when he was fighting with Britain at the Battle of Mekdela. Though Kassa lost his life, the situation of his death and challenges from internal and external forces gives a strong moral for others even for the present generations. This is because of Look what sentiment does the following last word of Kassa could create on the audience;

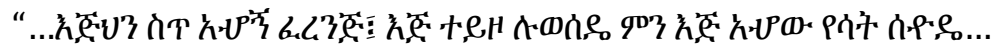

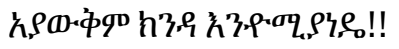

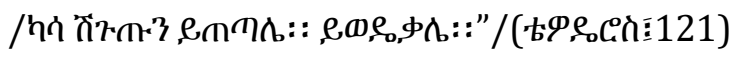

"My enemy said;

give me your hand, to take my hand ... What hands have a frying pan ...

As never mine! He does not know how to hurt this arm!!

/ Kassa packs his pistol. Falling. /" (Tewodros,121)

With no any precondition, the audiences give support to this action of Kassa and prepare himself to sacrifice him for his country to endure challenge. They picturized the problem he was faced, in mind and become ready for new adventure. 
In the play Menilek, the story about the administration of King Menilek from the beginning to the end articulates the theme that Ethiopia has internal and external enemies which try to terminate its journey to civilization. The treaty of Wuchale may be seen as evidence to show the external enemy and the war of Adwa may depict and maneuvers internal enemies in a best way. Wuchale treaty was a conspiracy to make Ethiopia the colony of Italy made by the Italian diplomat Conte Antoneli. In Adwa, it was not only the Italians who fought with Ethiopians, there was also Ethiopians who ally with Italy. Ras Alula reported this to Menilek as;

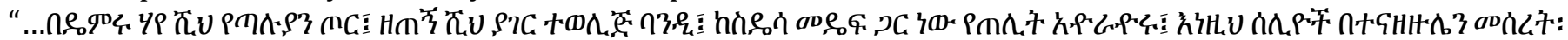

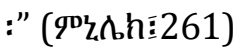

"... according to the information they gave, the enemy troop level is a total of twenty thousand Italian troops and nine thousand Indigenous Banda, with sixty Frogs." (Menelik,121)

Even though banda Ethiopians aided the Italians, the result of Adwa war was sided to Ethiopia. The treaty of Wuchale was also blocked by strong decision made by Menilek.

Based on the plays Ethiopia is a country with along and pride history in which its ancient empire covers large parts of Africa, Asia and Saudi Arabia. It also explained, as it is a source of civilization. The history that it posses is full of adventure ended with championship. This representation has a great value to create a sense of greatness and initiate audiences to take action that make Ethiopia great again.

\subsection{THE REPRESENTATION OF ELEMENTS OF ETHIOPIANISM IN THE SELECTED PLAYS}

\subsubsection{PATRIOTISM IN PETROS YACHIN SEAT, TEWODROS AND MENILEK}

The central issue of the selected historical plays is patriotism. Both the protagonists and the title of the selected plays; Hailu (petros), Kassa (Tewodros) and Menilek are icons of patriotism in Ethiopian history who are committed to sacrifice their life for their country. Their stele erected around the country could justify this. All actions and reactions in the plays are emanated from the spirit of patriotism. The fatigue to build unified and strong nation-state, the effort to resolve contradictory needs and deeds, the eagerness to create peace, stable and modernized Ethiopia, the scuffle to keep Ethiopia from foreign invader through war or diplomacy are motifs reccurring in the plays.

According to Deraman and Razak (2018: 85), loyalty and sacrifice for ones country are the major characteristics of patriotism. To achieve their patriotic goals, most of the characters, if we cannot say all, are with munitions of commitment to sacrifice their life for their country with no precondition, which is the main virtue of patriotism. Whatever, whenever and wherever anything comes againest the benefit, unity, sovereignty, and dignity of their country, they are willing to give their life as a gift. This concept is highly portrayed in the plays in a clear way. Let us demonstrate this by examples of extracts taken from each play.

In Petros Yachin Seat, death is depicted in a broad way like conception of Merlod Westphal. According to Westphal, death has two facets, biological and existential death. Biological death is a natural phenomenon that humans life is terminated and it may be timely (valuable) or untimely (unvaluable). Untimely death is a situation when someone die without fulfilling his/her objective and while timely death is a state when someone die after accompalishing his mission and become a light for future (Tewodros, 2001;154). These two facets of death are articulated in various situations in the play. Hailu or Abune Petros (pp.3) prefer to die a valuable biological death than exixtential death, which could bring something bright for others. This is occurred when Hailu, the symbol of patriotic Ethiopians, is argued by Rudolf and Mersh who symbolize External and internal enemy, respectively. Let us see this in the following extracts:

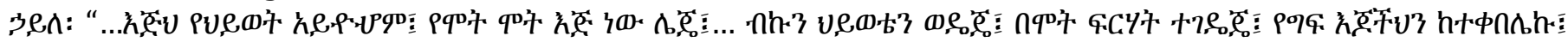

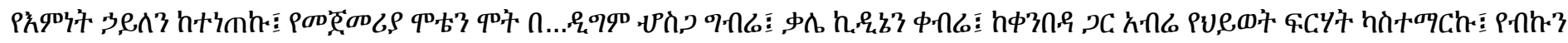

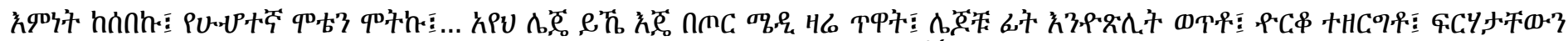
久

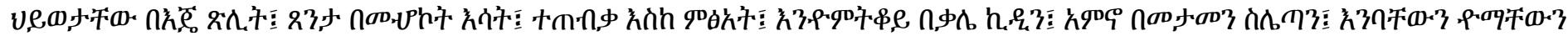

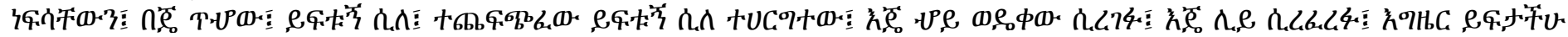

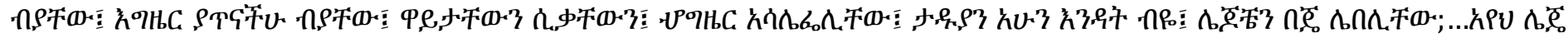

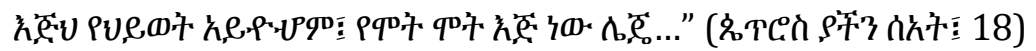

Hailu; "... your hand is not life; it is a death of death my son, I hate my life, my fear of dying, my injustice, my damn of faith; My first death to death was ... and I was killed in my death, fighting for my death, breaking my promise, and teaching my fiancee to the sword, killing my second death, and ... Seeing, my son was on the battlefield this 
Haimanot Wassie (phD), and Animut Getahun

morning, They had their fear, their courage, their burdens, their sorrows, and their hearts to my feet, and their ambassadors, and their lives in the hand of my God, and in the fire of the God of my salvation; For it is in my power to slay me. When my hands fell on one of them, when I washed my hands, fluttering with the feet, and seeing them fluttering, I would swing them to gag them." (Petros yachin Seat, 18)

The above quote is the answer given by Hailu to Italian Rodelfo when he asked to believe, as Ethiopia is colony of Italy and ordered him to teach Ethiopians to accept, as Italy is their formal administrator. Hailu told Rodelfo that, choosing existential death by fearing biological death is like dying a death of death and he does not have any place to answer his question positively. Insincerity to words and conflicting with goals are characteristics of this death of death what we call existential death. Hailu before he becomes captive of Italy, he was abettor of patriots fighting for freedom, absolution of their soul, and staves of their stability. For him, turning these words for he is under the hands of enemy is like what he calls "dead a death of death". Therefore, he prefers to scarify his life for his words, for his followers, and for his country as a whole. This is also expressed in the play through the form of advice when Mersha trying to argue and tempt Hailu to change the idea of life scarification as shown below:

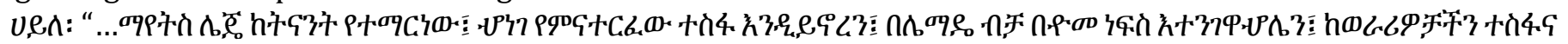

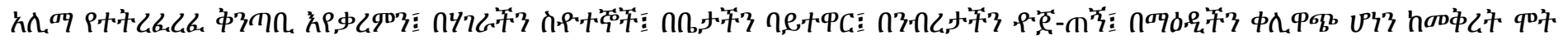

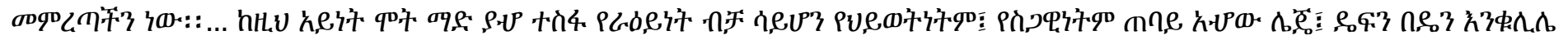

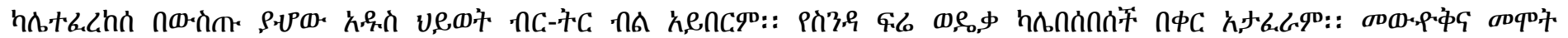

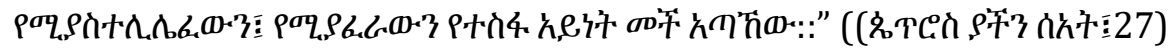

Hailu; "... My son, look what we was learned yesterday: being with out hope for the future of our lives, we will suddenly fall away with the hope of the invaders, the hope of the invaders, the abundant bounty of our country, the refugees in our country, It's about choosing our own death from leaving our nest in the stairs. ... Without hope, this kind of death is not just revelation but also life and dignity. My son If a solid egg is not stacked, it does not break into the new life of silver in it. it will not yeild unless it is crushed and rotted. You lost the kind of hope that gained from falling and dying". (Petros Yachin Seat, 27)

This is Hailu"s advise For Girsha that, cooperating with enemies who comes to destroy hope, culture, belief and property of motherland with the aim of getting benefit from them is not our history inherited from forefathers. Rather, dead a death that could bring life for others, a death that can create a number of heroes who can be a base for hope of tomorrow. This is the theme that the play at the end assured as the death of Hailu is such a death as, " ...

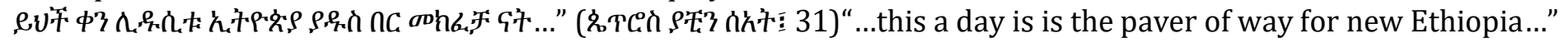
(Petros Yachin Seat, 31). What we understand from this explanation in Petros Yachin Seat is sacrifing oneself to Ethiopia is a virtue of patriotism which we learn from our ancestors. Surrendering the souvereign of our country and giving priotity for our personl benefit is not what we inherit from them. It is winning existential death, by dying a biological death we inherit and we should preserve.

In Tewodros, the decision and action of Kassa (king of Ethiopia) to commit suicide when Britain invaded his country and try to make him captive can best express the idea of sacrifice:

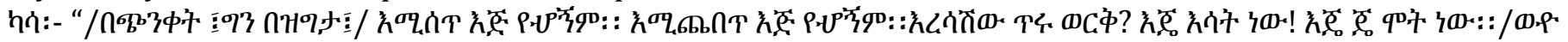
h.

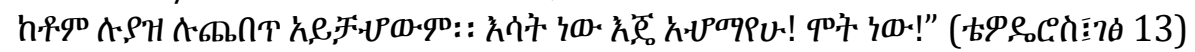

Kassa: -"/ Distress, but slowly/I do not have hands to be given. I do not have hands to be caught. Do you forget Tiruwork? My hand is fire! My hand is death. /by turning to Alemayehu/ look Alemayehu...look my son. This is what this country has been holding as a child in the arm, today it is impossible for a powerful monarch to regain power alone. Fire is my arm! It is death! \"(Tewodros, pp.113)

The above extract is taken from the dialogue between Kassa and Tiruwork at Mekdela when the civilized and organized force of Britain is going to assure as the winner of the war. Tiruwork argued Kassa to surrender his hand to the Britain force rather than fighting with them by stowing different atrabilious reasons that tempted the sprite of Tewodros to do what they say. Though Tewodros has knows that he has only one choice (death) beyond giving his hand, he does not change his stand. He decided to sacrifice his life (to die) for his country. He expressed this through simile of his hand with fire. The nature of fire is not comfortable to hold. Not only trial, but also thinking to hold it seems like utopians of catching fog with hand. It is impossible to do that. Through this, Kassa convey message to the audience as, the plan to make Tewodros captive of Britain is failed because of his decision to take the action of suicide. In addition to this, he also gave lesson, as giving hand is not the behavior of a hero or patriot. 
The argument between the characters Gelemo and Gebrye to take part a war with Wondyirad is another evidence for this theme:

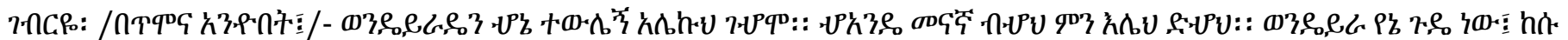

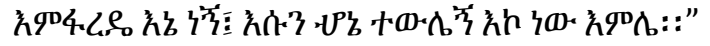

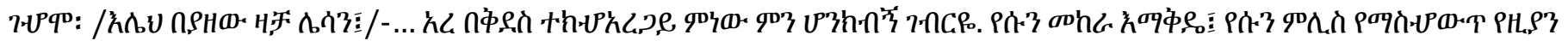

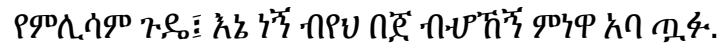

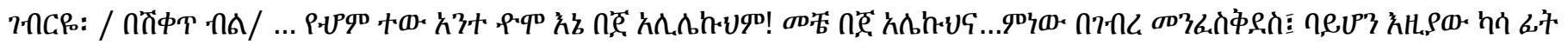

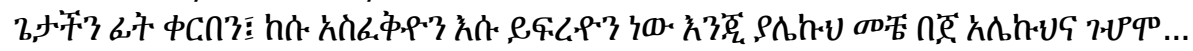

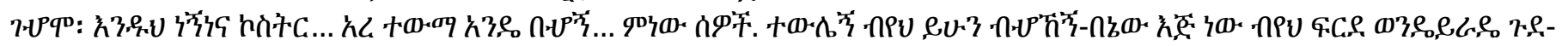

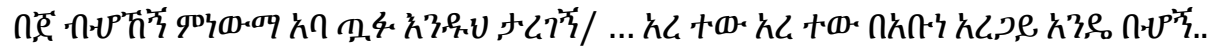

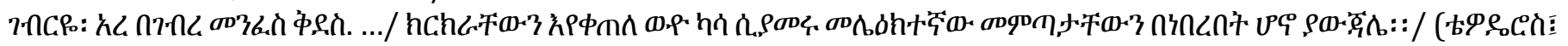
7' 53)

Gebrye: [In serious tone]: Leave Wendyirad for me Gelemo. What a gift to a stupid man.

It's mine; I'm in charge of it; you promise to give it to me. \"

Gelemo: / In the anger tone: /...Oh, what have you to do with me? Don"t you accept my plan to his hardships, and to change his tongue?

Gebrye: ..In the name of Gebremenfes Qidus, No, miss you, I did not tell you! When was that time you? ...rather I said, kassa our king will decide it.

Gelemo: ....In the name of Abune Aregawi...after you say ok, why do you regret back?

Gebrye:.. In the name of Abune Menfesqidus.../The process of restricting their dispute to Kassa will be announced by the messenger as they are arrived./ (Tewodros, pp.53)

The above character; Gebrye and Gelemo, are honorable manservant of Kassa, who outlawed on Menen"s administration and Wondyirad is a man of Menen. The above conversation is taken place between Gelemo and Gebrye when they hear Menen"s plan and preparation to capture Tewodros. They compute one another to sacrifice their life for Tewodros and his vision to create strong and unified Ethiopia, which was scrambled by nobility/judges of the era. Slay or quietus, engrossed or surrender, winning or succumbing, gaining or losing are events resulted from war. If the warriors are with fortune and power, they can either wine or capture enemies, unless, accepting the opposite will be their fate. Two warriors of Kassa; Gelemo and Gebrye, take commitment to admit all these states of war with full of heart and confidentially. The names of the saints they used between their arguments express this and their eagerness to participate in the war. In the culture of Ethiopian orthodox Tewahdo church, saints are highly respected icons. Abune Gebre Menfesqidus and Abune Aregawi are among respected saints who are given a day of feast at 5 th and 14 th date of each month respectively. Churches are also built by the names of this saints in different parts of the country. When someone asked, begged or told anything by calling the name of saints, it is believed as, truth and become initiative to take action. This shows how much both Gebrye and Gelemo sentiment is sensitive to their country, Ethiopia, than their life.

In the play Menilek, the dialogue between empress Taytu and Antoneli, diplomat of Italy, maneuvers the sentiment of Ethiopians, for their country and life as is evident from the dialogue below:

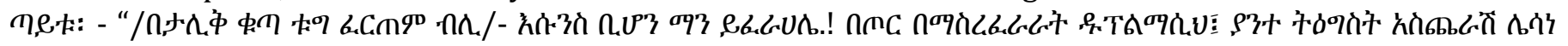

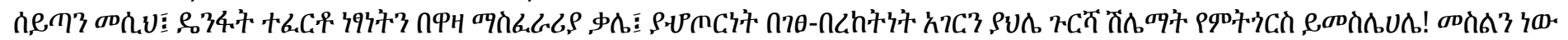

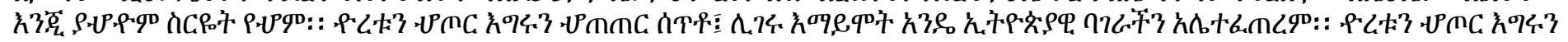

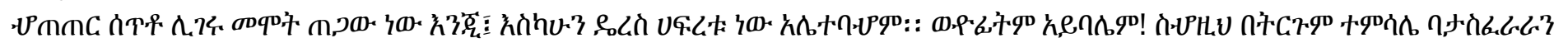

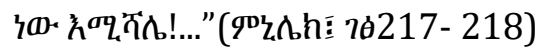

Taytu: “...(With great anger)- Whoever fears that!! In your military diplomacy, your merciless persecutor, you will think that you will win a prize as a blessing to a nation without prosperity! It does not exist but there need a blood. He gave his chest to the sword for a soldier to die for. He gave his chest to the sword, so he died, but he was not yet haunted. It will never be! So you do not mean to deceive us with a parable!" (Menelik, PP.217- 218)

The above extract is the answer given with anger and stubbornness to Antoleni. According to the narration in the play (pp. 219), the first convention of article 17 was exposed to language conspiracy. Due to that Menelik was calling the diplomat of Itay, Conte Antoneli, and agreed to amend it again. But Antoneli was coming up again with article full of words that harm the freedom of Ethiopia. During that time Menelik refused to accept that and Antoleni try to treat them by power and strength of Italy. Taytu told Antoleni as there is no one who regrets to sacrifice his life in Ethiopia, for Ethiopia. Death for his country is grace, not shame for everybody. 
Haimanot Wassie (phD), and Animut Getahun

Another virtue of patriotism depicted in the plays is being loyal to the country. This loyalty may be, on the one hand a loyalty of the king or leader to his country or the people, or on the other hand, the loyalty of the people to their country and for their leader. The sense of rendering priority for national dignity than personal fame is prevailed in the plays.

In Petros Yachin Seat, when Rudolf and Mersha tempted him to change his faith on Italy, they were the patriots he was with them and his country that obliged him to stay with his first stand. On the other hand, the play also shows, as his followers were loyal to him and his last word. They deprive Italy from their country and erect his monument at the place where he lost his life (pp.30-310).

In Tewodros, the dialogue beween Kassa and Tiruwork that taken place when Tiruwork advised him to give his hand and preserve his throne and Kassa refuse to do that, could explore this idea.

т⿻.

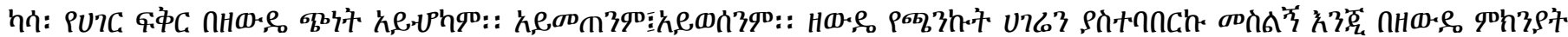

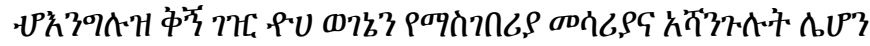

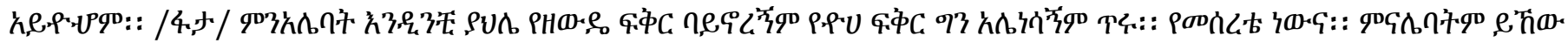

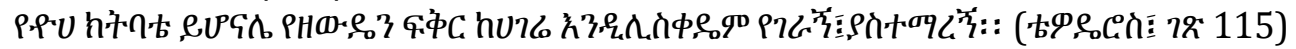

Taytu; "Okay, what will be your country? How about your crown?"

Kassa: National love is not a tribute to royalty. No, it does not matter. The crown was supposed to have been coordinated, but not for the sake of the Britain colonial rulers, not the puppet and puppet. May be I do not have love for crown like you, but I do have a great love of ordinary people. For, I am foundational. Perhaps this may be my vaccine helped me to give priority for my country. (Tewodros, PP. 115)

Facts of being loyal to the country he administers and to the people he leads are articulated in the above extract. On the one hand, the extract Kassa"s choice to his country than the crown shows his loyalty to Ethiopia. Crown is what everybody at leading position used to preserve his authority. But, Kassa refused to do that because why he saddle the crown is not to be proxy leader of colonizer, rather to unite his country.

On the other hand, the extract shows the loyalty of Kassa to the people he administer through his words. We hear him when he speaks of the love he has for the people is more than he loves a crown. As we understand from the story, Kassa did not change his word. That is because of this behavior he suicide himself at the end of the story.

In Menilek, The response of Ethiopians to the call of Menilek in Adwa campaign can be another articulator of loyalty that Ethiopians have for their king and country. When Menelik II declare a proclamation of, "...Enough! With the help of God, I will defend the inheritance of my forefathers, and will derive the invader back through forces of arms! Let every man who is strong join me! And who is not strong, let him pray for me!" on September 1996 G.C, to mobilize his people against Italian invasion, for they were patriot of their country and honor of their king, strong men defeated the Italian at the battle were joined and form the largest and best- equipped African force, which lastly win Adwa in 1996 G.C. This condition in the play is observed or stated, when Teferedech echoed this declaration of war campaign as reproduced herewith:

"/申LC.

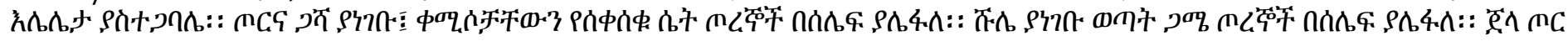

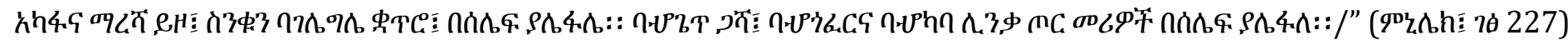

"It is going to ulitation and war cry.The horse's tongue and voice assesses ... The lady's whistle shouts. The trumpet and flute sounded war cry and joy. Women fighting warriors dressed in spears and shields would pass by. Shocked young gallop fighters will pass by. Jelly takes armor and plows, spinning the bowl and spinning. Wreaths of shields, warriors and fortune tellers were passed by." (Menelik, pp.227)

Bahiru Zewdie express this situation as, „Menelik"s javelin was inclusive in which participants were from every region of the country. Every one all around the country was subject of the war. $(1987 ; 85)$ This shows that the story in the play is going parallel with the real history and Tsegaye used this good quality of Ethiopians in order to initiate them to possess loyality through art.

The monologue of Sebastian, show how much Menilek is loyal to his country and his people who are loyal to him.

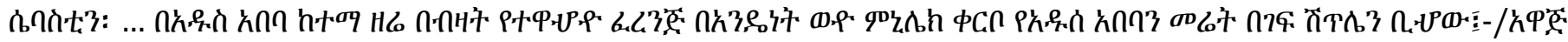
内 • 
Sebastyan; “... many foreigner who born in Addis goes together to menilek and ask him to sell a bulk of land. He answered as he is a great landlord of Habesha, not a seller. I have no inheritance of my own field. So I can not sell or sell land to anybody, so he hurries over." (Menelik, pp.244)

Kings have a power to own everything, because no one ventures to ask them. There was no rules and regulations that make them accountable. Menilek as a king, as we observe from the above extract, does not have even one-meter square land for himself in Addis Ababa. He gave the property of land to the people by telling foreigners that his work is keeping the the land of Habesha not retailing the land. In other words, he told them, as he is the custodian of the people.

All the above forms of loyalty, i.e, loyalty of people to the king/leader and their country, and loyalty of the king to the people and his country, shows as loyalty is one virtue of patriotism practiced in the historical plays parallel with the actual historical events express Ethiopia and Ethiopianism best.

From the above analysis, we understand that patriotism is the main virtue of Ethiopia and Ethiopianism in the selected historical plays. It is the decision to sacrifice life for their country, the loyalty of the leader to the people, and the loyalty of the people to their leader that help the character to achieve their goals. The commitment of Hailu resulted Ethiopia to be free from Italian occupation, the decision and way of suicide taken by Tewodros armed strong moral of patriotism, the patriotic action of menelik during his leadership-helped Ethiopia to possess civilization and to win Adwa. We also understand as the writer used constructive historical events to build the story, which make it thrustworthy.

\subsubsection{UNITY IN PETROS YACHIN SEAT, TEWODROS AND MENILEK}

The second element of Ethiopianism depicted in the plays is unity. This is expressed throughout the stories in different ways, directly or indirectly.

In play Tewodros, Kassa speaks of unity, as it was one best and historical virtue of Ethiopiansm in a brief way, as quoted bellow:

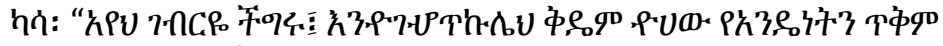

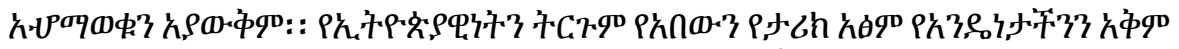

UPUרC 491'

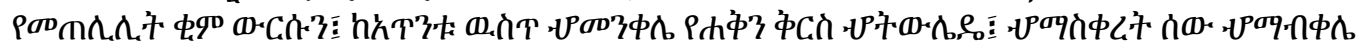

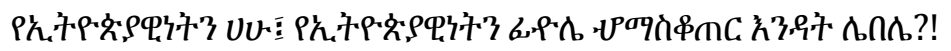

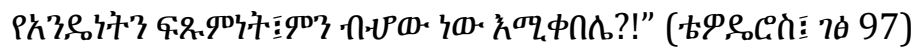

Kassa; "You see Gebrye, as I explained earlier The poor is not wisecare

The meaning of Ethiopia Our forefathers history The power of unity

For the liberty of nation, not for racial revenge For the benefit of invader, not to tear each other. depriving hatred, for pulling out of his bones.

How to count the Hemstone for generations, to grow a man to keep it up. How to count the Ethiopic, alphabet of the Ethiopians !?

how will they accept the unity"s perfection?!" (Tewodros, pp; 97)

The above extract in line 8, symbolizes unity as "Ethiopianism HaHu orAB" and "Ethiopianism letter". HaHu or $\mathrm{AB}$ is the first letter that the learner knows during the first time of formal education. Even, it is a letter that we hear from human being at the first times of his/her born. Words, phrases and sentences are constructed by letter in the next step. As a letter is the basis to know the four skills of language, Kassa express unity as it is the basic issue to understand Ethiopianism. It is the base of our history used to fight for freedom, a means to avoid revenge and a solution for disagreement. In other words, this convey a message that the absence of unity lead to internal conflict and weaken the central power of the country which in turn expose to external invader.

The writer also used demeaning of others as a technique to bring unity in the country. Kassa condemn those who are working to erase unity for the sake of authority as;

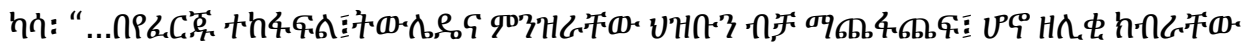

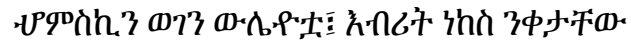

(...)

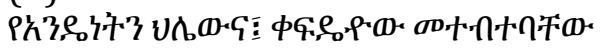

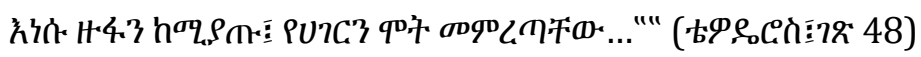


Kassa; “... They are divided into groups, generations, and inmates It's just a massacre of people, their lasting glory

For the Cyprus, their arrogant ignorance. (...)

The existence unity, thorned by them

For they prefer their country"s death, than their crown."( Tewodros, pp.48)

Kassa describes them as they are anti unity that give priority to crown than their country, abnegator of the ruled, that do not believe in human equality and are a source of conflict between the people. He used this expression to expose their bad doing and to be hated by the people. This in turn helps him to get support.

He also show the solution by taking a commitment to punish those who conspire to kill the unity of Ethiopians as:

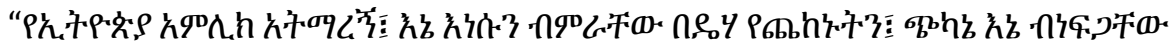

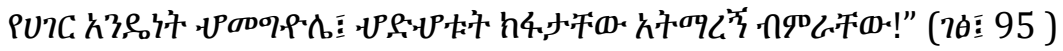

"Do not mercy me the God of Ethiopia; if I mercy them

If I ravaged them, cruel on the poorest For their evil, to kill the country unity,

Don"t mercy me, if I mercy them."( Tewodros, pp.95)

In Menilek, the main character Menilek himself announce the need and deed of unity for the continuousness of Ethiopia by proclamation as;

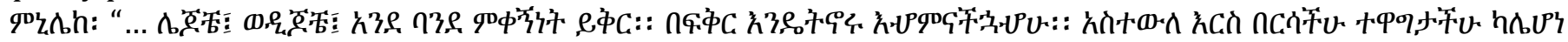

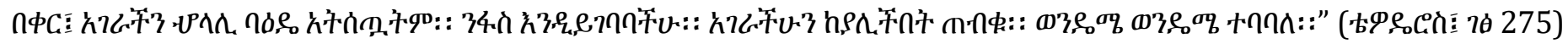

Menilek; "...My children, my friends, on one hand jealousy. I urge you to be in love. You do not give our country to another stranger, unless you fight with each other. Do not get windy. Keep your country safe. My brother my brother. \"(pp. 275)

In addition to the above direct expression of unity, the plays show the pros and cons of unity practically. In Tewodros, the sprite of unity among Tewodros and his army, as well as between warriors helped Tewodros to wine various wars. He defeated Etege Menen at the battle of , Ras Ali at the battle of Gorgorabichen, Dejach Goshu at Gur Amba, Dejach wube at Derasge and this finally crowned him as King of King for Ethiopia. On the contrary, the absence of unity leads Tewodros for suicide and Ethiopia to lose many wealth and heritage as explained by Terefedech as follow.

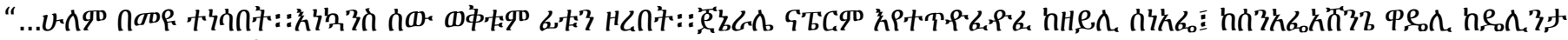

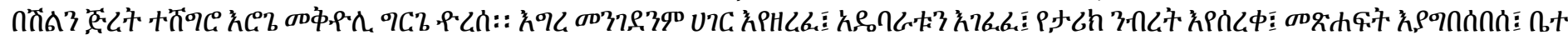

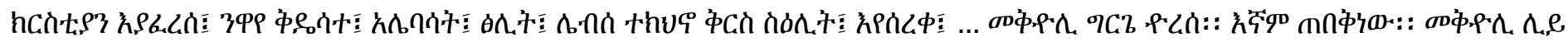

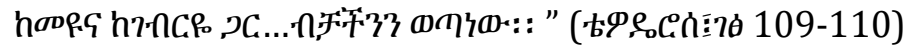

"... all came to light. Someone turned his face around. General Naper was thrown to the bottom of the Mekdela. On the other side, he was robbing the store, stealing books, stealing books, stealing books, stealing books, stealing the church, stealing, ... docked at the foot of Mekdela. We waited him. At Mekdela with Meyu and Gebrye ...we went out alone." (Tewodros, pp.110)

In the play Menilek, Adwa the major historical event that makes Ethiopia known in the world is a result of unity. All Ethiopians were marched to participate in the war. This is observed in the play when we discuss about loyality above.

The prevalence of unity in the play Menelik also expressed through the construction of the whole play. When we say the construction of play, it is to mean the language used, ethnic group, religion and name of the character participated in the play. In the play, characters are from different ethnic, multilingual and multi-religious groups. This difference does not prohibit them to work for the same objectives. To justify this let us look some names of characters participated in:

“Gobena Daki (pp.158),... Girmame (158),...Dechasa Leka (159),...Bedane Alka(198), Umer Beksa(200), Menilek (3).., Aba Matiwos (215)

The above are some of the names used to call the character in the play, which are oromifa, Amharic and Tigrigna. Further, the naming shows as there are Christian and Muslim participants. Here, according to Derman and Razak (2018: 93-94), the presence of diversified characters marching to the same objective represents unity among them.

On the other hand, the use of different dialects or language in a multiracial nation shows public as they are with rich culture and convention to live together. Thus, the usage of different languages in the play shows respect for the different communities (ibid). The following is a song in Oromifa that illustrate the use of different language: 


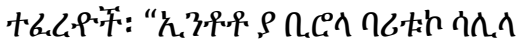

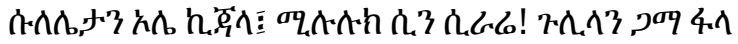

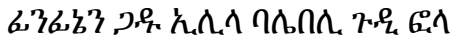

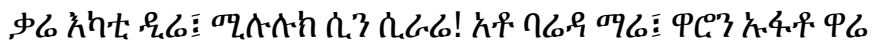

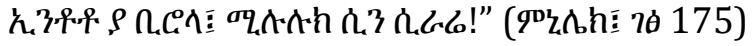

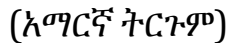

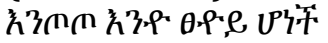

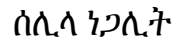

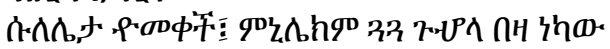

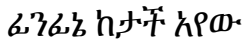

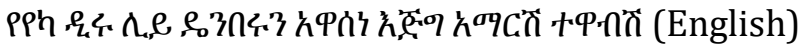

Intoto blossoms like spring

Also a day for Selale

Sululta glitter, and Menelik feel eager Gulele expnded on its side

Finfine view from the bottom

The verge of Yeka bourdered the boundary Extremely it looks good.

The above song conveyed a message about the growth of Intoto and the eagerness of Menilek for its change.

From the above discussion we can understand as unity is depicted in the selected plays directly, indirectly and symbolically. The base for the presence and survival of Ethiopia is, unity. The analysis explores to preserve this element by presenting it with historical evidences.

\subsubsection{HOSPITALITY IN PEROS YACHIN SEAT, TEWODROS AND MENILEK}

Hospitality is another element of Ethiopiamism portrayed in the three plays. Hospitality involves welcoming strangers - not just the rich and respectable strangers, but also the oppressed, persecuted and absolute strangers who may not posses much to share or with whom one may not always have much in common. Strangers may be those, "who comes today and goes tomorrow" or "who comes today and stays tomorrow" and may also be from abroad or within a group. In the selected plays, hospitality is portrayed in various ways (Puspa, 2012:1-2).

In the Tewodros, the dialogue of Bel with Menelik can express the extent of Ethiopians hospitality as mentioned below:

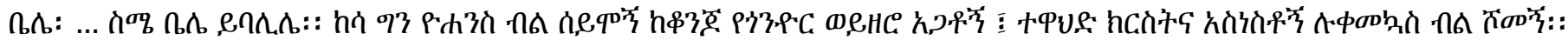

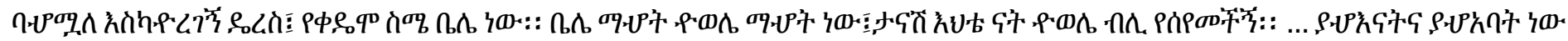

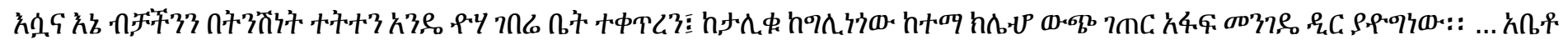

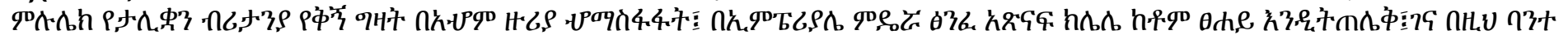

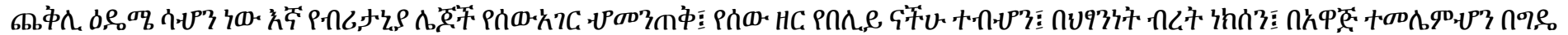

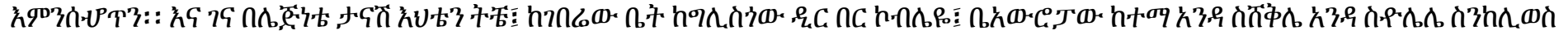

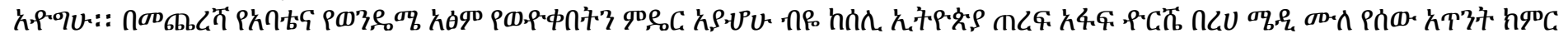

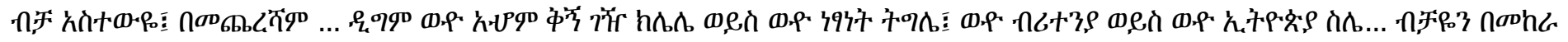

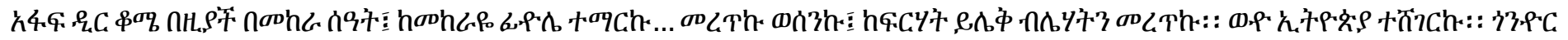

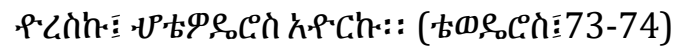

Bel: “ My name is Bel. However, Kassa named me as Johnny, make me Christian and give authority. As long as I'm eligible, my previous name is Bel. It means a bell, my little sister called me a bell.... She and I were left alone and we were left alone and saved by a poor farmer. We grew up in the edge of the remote town of the town of Gilaskow. Abeto Menilek, United Kingdom to expand its territory, it told us a human being of the highest rank in the world, and obliged us to be a soldier. And when I was a little older, I left my sister from the farmer's house, Glasgow's Berkeley Cobbler, and I went to the city of different Europian country. I finally was coming to saw the gravity of my father and brother"s on the edge of the coast of Ethiopia, and finally ... I was standing by the abyss to the colonies or the struggle to freedom, to Britain or to Ethiopia ... ; I learned from my affair ... I chose it, I chose a skill rather than fear. I was transferred to Ethiopia." (Tewodros,pp.73-74)

The above extract is a story of Bel taken from a dialogue between Menilek and Bel when Menilek is under the situation of fear and tension due to his departure from his family by Tewodros. This was used as a tool to convince Menieik that hospitality is the best virtue of Tewodros's administration. Bel is an oppressed stranger from Britain 
Haimanot Wassie (phD), and Animut Getahun

lived under slavery. He grows without family because of Britain"s colonial policy. He lastly decided not to go back to that colonial world and to live in and for Ethiopia, which is a symbol of freedom. When he came, Ethiopia accepted him and gives great dignity like wife, baptism and authority. He explains that Ethiopians were not treated as an enemy. Through this story what Bel told to Menilek is,

„Tewodros who gave such a dignity for those who are from abroad, could not fail to give much freedom and respect to his relatives who comes from his country."

In the play Menilek, the situation of handling journalists coming from abroad can best described that hospitality is one element of Ethiopia and Ethiopianism. This is expressed by menilek, on the one hand, the voluntariness for interview by giving priority for stranger journalists than his work. This idea is stated as;

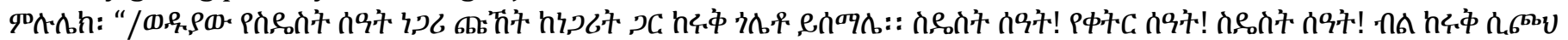

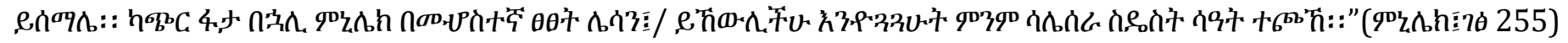

Menelik; "/ Immediately, the six-hour screaming loudspeaker stands out from the distance. Six o'clock! Late afternoon! Six o'clock! He hears the cry from far away. Shortly after the break, Menelik with a bit of regret. /Here are six hours of screaming, without doing nothing as my eagerness." (Menelik,pp.255)

The above extract shows the dignity, that the journalists get from the king. It was in the early morning the journalists were coming to Menilek when he was participating in works of Arada Giorgis church renewal. In Ethiopia, church has a great dignity. But Menilek gives interview by interrupting his work. The strangers take priority than the work. This shows that how much Menilek (the symbol of Ethiopia) has a place for strangers.

On the other hand, the invitation for the journalists explores the hospitality of Menilek as shown bellow:

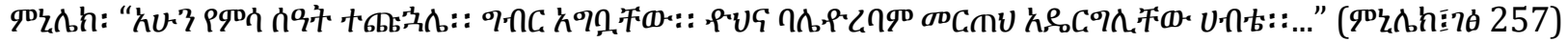

Menelik; "Lunch is reached now. Take them to Gibir (lunch party). Choose a good friend for them Habtie." (Menelik, pp.257)

The above extract shows the way how journalists coming from America, France, Italy and Caribbean are handled. Gathering different information about the country is their purpose of coming. From the side of Ethiopia Habtegiworgis and Eagle was the agent who create comfortable condition for them. With the help of these agents, the journalists meet with menilek and get information what they want. After the completion of interview Menilek does not let them alone to go, rather he invited them to participate in lunch Gibir.

According to Abriham, the meaning of hospitality based on the Bible New Testament (Luke 10:20-37) is a human mercy ( Puspa L,2012:28).

This type of hospitality portrayed in the play of Petros Yachin Seat as;

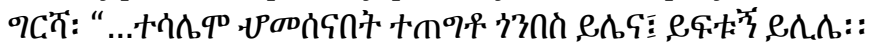

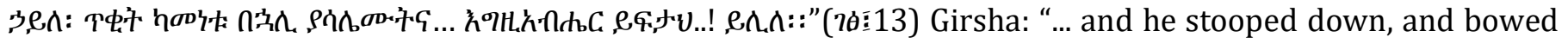
himself to the ground.

Hailu: After a few moments of craving, ... God will divorce you! he say."(pp.13)

Girsha is enemy of Hailu who tempted his patriotic feeling to his country. But, Hailu give him a mercy and excuse for him.

In the play Tewodros,the mercy of Kassa to Menen can best express this types of hospitality as mentioned here:

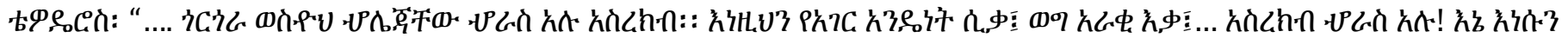

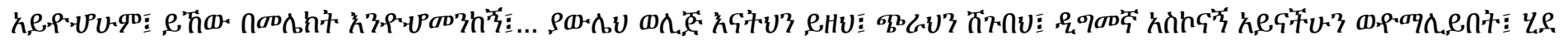

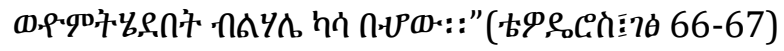

Tewodros; “.... Take her to Gogora and serve to Ras Ali, her son. Take these anti public unity and gave her to Ras Ali. I'm not like them. Tell Ali I said, according to your begging, take your mother, the parent that you live with, , and go ahead." (Tewodros, pp. 66-67)

The above extract is taken when the following situation is happened. Etege Menen was going to a battle to capture or kill Tewodros. The situation was not like what she planned and she became captive of him. However, Tewodros after he receive a letter of Rass Ali, who was fleed to Gorgora, he give mercy for her and let her to go to Ali. The letter contains recognition to Tewodros"s administration and begging idea to cede Menen.

In the play Menilek, the mercy that Menilek gave to those captives from war of Adwa can express this type of hospitality as follows:

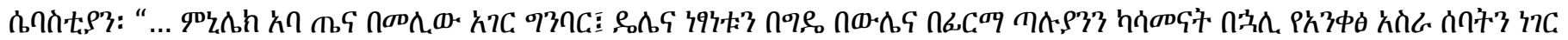

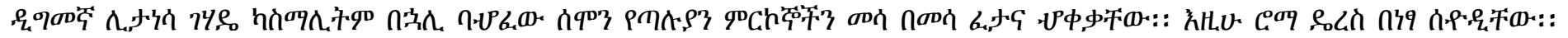
90 Ch'大 


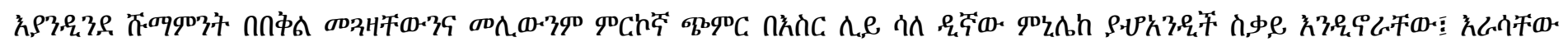

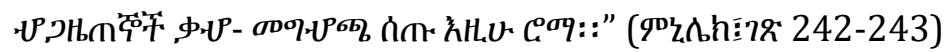

Sebastian; "....MenilekAfter a year of solidarity and freedom in the country, he defied the Italian captives and released the thugtators of the article after he had recaptured not to rise the article. He sent them to Rome freely. The exiled General and other captives were not get Menilek as they afraid to go from Adwa to Adis Ababa without shoes, but each of the officers had to walk on mule and while they were in prison, they had to carry on their backs. The captive themselves give press release." (Menelik,pp. 242-243)

It was after the victory of Adwa the situation explained in the above extract is happened. There were many captives from the war. The handling given to these captives was interesting and amazing to express. Menilek offered mule for journey from Adwa to Addis Ababa. All the arrested were seen off peacefully. This shows that hospitality was one virtue of Ethiopianism practiced in Menilek"s administration.

The discussion above about hospitality shows as it is one element of Ethiopianism that Ethiopian possesses from antiquiety. To express how much they are hospitable to strangers, the writer depicts and articulates their acceptance of foreigners either who comes today and goes tomorrow" or "who comes today and stays tomorrow. That is the absence of this quality, that increased the number of immigrants in Ethiopia currently.

\subsubsection{FREEDOM AND INDEPENDENCE IN PETROS YACHIN SEAT, TEWODROS AND MENILEK}

Historically, Ethiopia is free and independent from any external invader. From the very existence it had never lost its freedom. This is expressed in the selected plays and offer solutions how this could be preserved.

In the play Tewodros, freedom and independence of Ethiopia is expressed in the following way:

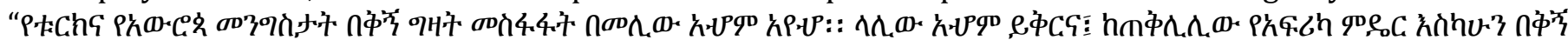

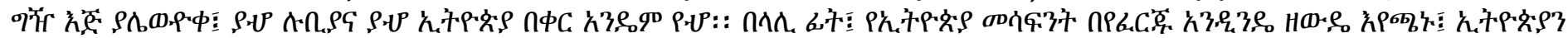

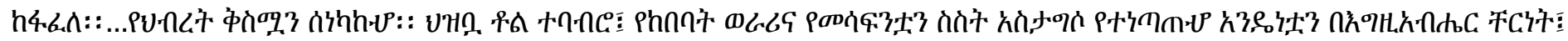

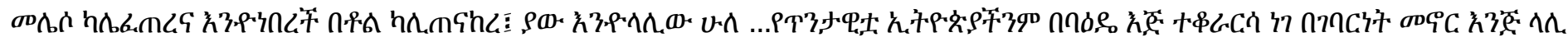

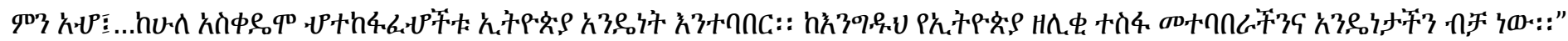

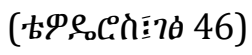

„The colonial power of Turkey and Europe has expanded all over the world. Except Ethiopia and Libya, most frican countries are colonized. On the other side Ethiopian nobles crowned in each and devided their country. This hobbles its unity. If the people does not stand together to breake this situation, the fate of our ancient Ethiopia will be, being under the yoke of colonial powers,...before anything else, let us unite for the devided Ethiopia. Only cooperation and unity is the hope of Ethiopia" (Tewodros, pp.46).

The above extract shows, as Ethiopia is one of the countries in the world that is not colonized by authocrat governments. In addition to this in the extract, we get the means how to preserve this pride history. Unity is the very essential element to be possessed in order not to invade by colonial powers. The weaknes to be united, paves the way to be invaded. That is our forefathes/mothers history of unity, which make Ethiopia and Ethiopians historic nation.

In Petros Yachin Seat, the issue of freedom and independence is heared from Hailu when he was at the eleventh hour to be executed. He orderd his followers not give up their hand to enemy and preserve the history of freedom as;

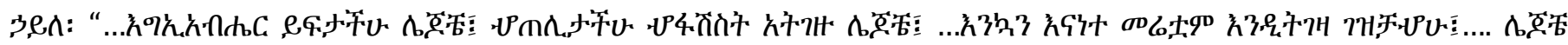

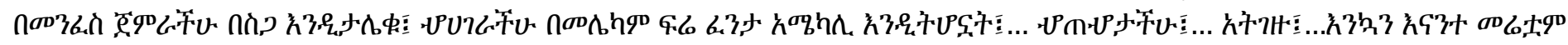

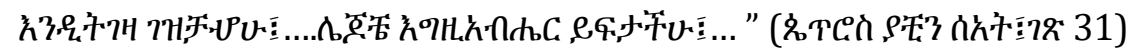

Hailu; "... O ye daughters of God, do not submit to adversity for your enemies, my little ones; not only you but also the land. Beginning with the Spirit, you have not last of the flesh. Do not make you a thorn to your country than a good fruit ... to your enemy, 0 ye daughters of God, not only you but also the land do not submit to adversity for your enemies." (Petros Yachin Seat, p.31)

In Menilek, the writer explains that its freedom and independence is used as the means to free other countries colonized by colonial pawer. This is presented in the following manner as;

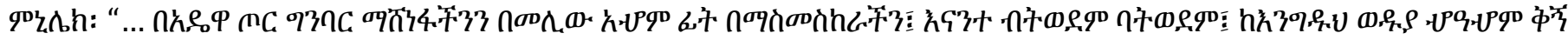

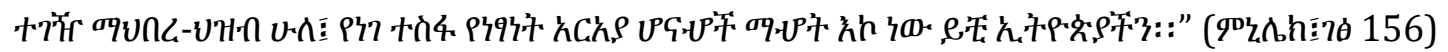

Menelik; "...We admitted our victory in Adwa all over the world, either you love or you do not like it, and for longer to the the colonial people, the future of hope as a model of freedom here is Ethiopia." (Menelik ,pp. 156)

International Journal of Engineering Technologies and Management Research 
Haimanot Wassie (phD), and Animut Getahun

The above extract is taken from the answer when Menilek gives interview for journalists. Wilde, one of the journalist, asked a question of, „do you think other colonized African could make you and your country as a role model for their freedom fighting?". Then Menilek answered as the freedom of Ethiopia is used like a role model for other countries. This shows how much the freedom of Ethiopia has influence in the world.

Finally, New Historicism is considered to be method of exploring how literature brings some understanding to current problems and it makes critic talk about the problems while talking about the plays.thus, from the above all analysis we can understand that Ethiopia and Ethiopianism is represented in the way that can create a good image on audiences by using history. Based on the actual history the writer conveys his messages artisticaly. The relationship between the actual history and the story in the play going parallelely. If there is, the only difference is the way of expression. In the play, major historical events, like the last time of Tewodros, Petros, and the battle of Adwa are articulated in a way that can create more image than historical books tells. To examine how these major historical events are represented in the play, it is important to campare it with the narration of actual historical event.

When we start from the history of Abune Petros, historians may explain his adventure as, „Abune Petros was a patriotic religious leader who was executed by Italian authocrats because of his denial to accept Italian colonial administration". (Bahru,1987;54)

While in the play this situation is articulated in a more imagery form. All the sentiment happened to Hailu is presented in a detailed way. The audience hear his argument with banda Ethiopians and authocrat Italian. They felt his loneliness to challenge enemies, his sickness to accept their mission and the adamant to sacrifice his life for the sake of his country through words the writer used.

The suicide of Tewodros at Mekdela also has the same way of narration like Abune Petros. In history the situation is expressed as, „Tewodros was a patriotic leader with a big dream to create united and strong Ethiopia and to make his dream real, he took various measures. The measure he had taken was, the incedent to be alone and he lastly take suicide in a fight with Britain at the battle of Mekdela." (Bahru,1987;31)

While in the play, the writer characterize Kassa and speake all his feeling in a detailed way. The battle of Adwa is another major event represented in the play. Like wise to the history of Abune Petros and Tewodros, the actual historical event expressed was in a way that states each happening in historical language. But in the play each and every events are presented by using artistic and imagery words that can create more feeling on audiences. The expression of Menilek"s feeling when Italy was started to invade Ethiopia, can be the best evidence for this.

The representation of the major historical events in the three plays follows the same pattern. They make the actual history as a base of their story. They did not exaggerate it, but they are presented in a way that can create a national feeling on audiences. In the plays, Tsegaye try to create a national hero through art. He articulates the main deeds of his hero by using artistic language. The year that the plays was written tell something bout this. Petros Yachin Seat was written in 1955, Tewodros in 1960 and Menilek in 1982. The actual historical events happened around 1928, 1962 and 1988 E.C respectively. Telling history is not the writer"s main objective, rather he wants to inject the audience about Ethiopia and elements of Ethiopianism that were with our forefathers and make them the winner of every campaign through the national heroes. He tries to inherit historical behaviours of Ethiopia and Ethiopians to generations,i.e, to possess the quality of patriotism, unity, hospitality, and freedom and independence to challenge problems they face in their life.

\section{CONCLUSION}

The study attempted to analyze and interpret the representation of Ethiopia and Ethiopianism in selected historical plays of Tsegaye Gebremedhin by using the new historical theoretical approach. Based on the findings, the following conclusions are drawn.

The selected plays reflect Ethiopia"s long history of civilization, historicness, and greatness. The plays do also play a significant role to instil elements of Ethiopianism and these elements are patriotism, unity, hospitality and, freedom and independence, which are critical to greatness and littleness of Ethiopia. The existence of these values is beneficial, and the absence brings harm. To show this, elements of Ethiopianism in the play are depicted in different manners; directly, indirectly and symbolically. Patriotism is the main virtue of Ethiopia and Ethiopianism in the selected historical plays. It is expressed through the decision to sacrifice life to their country, the loyalty of the leader to the people, and the loyalty of the people to their leader that help the character to achieve their goals. Unity 
is depicted in the plays, as it is the base of Ethiopian history. The pride historical events expressed in the plays are results of unity among Ethiopians.

Hospitality is another element of Ethiopianism practiced in the plays to portray what Ethiopians are for stranger. Based on the analysis, Ethiopians are hospitable not only for Ethiopians, but also for foreigners. It is expressed through accepting of foreign as well as domestic strangers and giving mercy to people. Freedom and independence is another elements of Ethiopianism articulated in the plays. Ethiopia had never been colonized by authocrats since its existence. The adventures perpetuated in the plays are to preserve this value of Ethiopianism.

The analysis also explore as literature is constructed from history and gives access to understand the past and to create present and the future. The selected plays depict the actual history of Ethiopia with no exaggeration, but in a way that can create a national feeling on audiences. Generally, the analysis shows that this representation of elements of Ethiopianism has a great role to advocate and promote the sense of Ethiopianism than ethnicity.

\section{SOURCES OF FUNDING}

None.

\section{CONFLICT OF INTEREST}

None.

\section{ACKNOWLEDGMENT}

None.

\section{REFERENCES}

\section{Primary Sources}

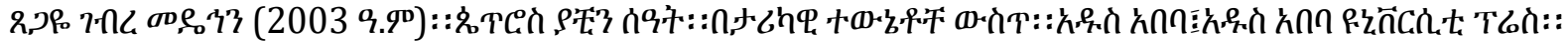

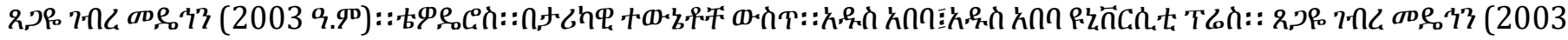

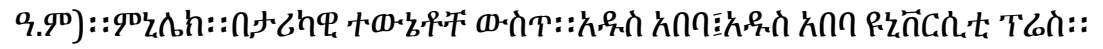

\section{Secondary Sources}

\section{Amharic}

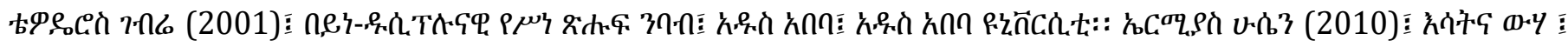

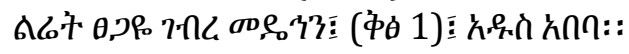

\section{English}

[1] Anteneh Aweke (2014). The Representation of Ethiopian Politics in Selected Amharic Novels: 1930 - 2010. $\mathrm{PhD}$ dissertation, for the degree of Doctor of Philosophy in the subject Theory of Literature, University of South Africa.

[2] Ayele Bekrie (2004). Ethiopia; Some Historical Reflections on the Origion of the Word Ethiopia. International Journal of Ethiopian studies, Vol 1, No.2, (winter/spring), pp.110- 121.Retrieved 09-06-2019 from http://www.Jstor.org/

[3] Bahru Zewde (1987). A History of Modern Ethiopia: 1855-1991 (1st ed.). Addis Ababa: Addis Ababa University Press.

[4] Bart, Bonikowski (2008). Research on American Nationalism: Review of the Literature, Annotated Bibliography, and Directory of Publicly Available Data Sets.

[5] Creswell, J. (2007). Qualitative Inquiry and Research Design; choosing among five approaches. sage Publication, America.

[6] Puspa, Damai (2012). Welcoming Strangers: Hospitality in American Literature and Culture. 
Haimanot Wassie (phD), and Animut Getahun

[7] PhD dissertation submitted in partial fulfillment of the requirements for the degree of

[8] Doctor of Philosophy in subject of American Culture and English Language and Literature in the University of Michigan.

[9] Deraman, Nurul and Razak, Fariza. (2018). A Study of Unity and Patriotism Elements in Film Ola Bola: A Thematic Analysis. Journal of Media and Information Warfare,Journal of Media and Information Warfare Vol. 11(2), 80-107, Dec 2018.

[10] Rogers, J. A. (1982). The real facts about Ethiopia. Black classic press, Atlanta University.

[11] John, Jackson (1939). Ethiopia and the Origin of Civilization. A Critical Review of the Evidence of Archaeology, Anthropology, History and Comparative Religion: According to the Most Reliable Sources and Authorities.

[12] Merara Gudina. (2003). Competing Ethnic Nationalisms in Ethiopian and the Quest for Democracy.

[13] Molvaer, KR. 1980. Tradition and change in Ethiopia: social and cultural life as reflected in Amharic fictional literature ca. 1930-1974. Leiden: Brill.

[14] Okolo, MSC. (2007). African Literature as Political Philosophy. CODESRIA Books. Dakar, Senegal.

[15] Punkhrust, Richard (2005). Historic Image of Ethiopia. Shama Publishing, Addis Ababa, Ethiopia.

[16] Hisham, Rahman (2016). A Study from a New Historicist Approach of Arthur Miller's

[17] Death of a Salesman. M.A thesis, Department of Foreign Language and Literature, Middle East University.

[18] Solomon Tesema. (2007). "Interdisciplinarity in Tsegaye G/medhin's Hahu weym Pepu".

[19] M.A thesis, Department of Foreign Language and Literature, Addis Ababa University.

[20] Tewodros Hailemaryam. (2013). A history of nationalism in Ethiopia:1941 to 2012.PhD dissertation, for the degree of Doctor of Philosophy in the subject History, University of Addis Ababa.

[21] Wallis B. (1928). A history of Ethiopia. VI-VII. Shama Publishing, Addis Ababa, Ethiopia.

\section{INTERNET AND WEBSITE SOURCES}

[1] Arjun, Dubey (2013). Literature and Society. IOSR Journal of Humanities and Social Science (IOSR-JHSS) Volume 9, Issue 6 (Mar. - Apr. 2013), PP 84-85e-ISSN: 2279-0837, p- ISSN: 2279-0845. Retrived Jan. 15/2019 from www.Iosrjournals.Org.

[2] Gebrewold Belachew. (2009), Ethiopian Nationalism: an Ideology to Transcend All Odds, in: Africa Spectrum,44, 1, 79-97. Retrieved Jan. 15/2019 from www.africa-spectrum.org.

[3] Chika, Christine, PhD. (n.d). Drama as an Instrument for National Identity Formation. UJAH UNIZIK Journal of Arts and Humanities. Retrived 17/3/2019 from *http://dx.doi.org/10.4314/ujah.v14i3.3

[4] Doğan, E. (2005). New Historicism and Renaissance Culture. Ankara Üniversitesi Dil Tarih- Coğrafya Fakültesi Dergisi, vol. 45, no.1, pp.77-95. Retrieved 14/6/ 2018 from villanova.edu/ silvia.nagyzekmi /teoria2010/.

[5] James, Quirin. (2010-2011). W.E.B. Du Bois, Ethiopianism and Ethiopia, 1890-1955. International Journal of Ethiopian Studies,Vol. 5, No. 2 (Fall/Winter 2010-2011),pp. 1- 26. Retrieved: 28-11-2018 from https://www.jstor.org/stable/41757589.

[6] Helmut K. and Aynalem A. (1989). The Ethiopian Population: Growth and Distribution. The Geographical Journal Vol. 155, No. 1 (Mar., 1989), pp. 33-51 (19 pages). Retrieved March. 13/2019 from https://www.jstor.org/stable/635379

[7] Vijay, Mishal. (2015). Nationalism and Spritualism in selected novels of Raja Raoand Rabin Dranath Jagore; critical study. An International peer-review open access journal, Volume 4, Issue 1(2017), (pp, 1-19), Retieved 20- 04.2019 from https://langlit.org/vol- 4-issue-1-part-i

[8] Teshome Abera. (2017). Ethiopianism principles. Imperial Journal of Interdisciplinary Research (IJIR), vol3, issue-5,2017, PP,1828-1832, Retrieved 20- 02.2019 from http://www.online journal.

[9] Tolstoy, Leo. (1988). What is Art? (Alymer M. trans). Retrieved 18/4/2019 from Web.mnstate.edu/.../phil\%20 of\% 20 art/tolstoy on art.

[10] Wilson J. Moses. (1975). The Poetics of Ethiopianism: W.E.B. Du Bois and Literary Black Nationalism. jstor, Vol. 47, No. 3 (Nov., 1975), pp.411-426, Retrieved 28-11-2018 from https://www.jstor.org/stable/2925341, 